\title{
Tourism Demand Modelling and Forecasting: A Review of Literature related to Greater China Gang $\mathbf{L i}^{1}$
}

\begin{abstract}
Greater China, including Mainland China, Hong Kong, Macau and Taiwan, contributes significantly to both regional and global tourism developments. Empirical research on tourism demand modelling and forecasting has attracted increasing attention of scholars both within and beyond this region. One hundred and eighty articles are identified that were published in both English and Chinese language journals since the beginning of the 1990s. This study presents the largest scale of literature survey on tourism demand studies. Furthermore, this is the first attempt in tourism demand review studies that focuses exclusively on one geographic region and covers bilingual literature. Particular emphasis of this review is placed on research development, geographic focus, data type and frequency, measurement of tourism demand, modelling and forecasting techniques, demand elasticity analysis, forecasting exercises and emerging research trends. Comparisons between the two bodies of literature published in two languages show a number of research gaps, such as the diversity and sophistication of the research methodology, rigour of the modelling and forecasting process and theoretical foundations of demand analysis. Correspondingly, constructive recommendations are made to further advance tourism demand studies related to Greater China.
\end{abstract}

Keywords: Greater China, Tourism Demand, Forecasting, Modelling, Review

\section{旅游需求建模与预测：关于大中华区的文献述评}

\begin{abstract}
李刚
包括中国内地、香港、澳门和台湾在内的整个大中华区对亚洲及全球的旅游发展一 直贡献巨大。大中华地区内外的学者对旅游需求建模和预测的实证研究也越来越重 视。自 1990 年初以来, 共有 180 篇关于旅游需求模型和预测的实证研究在中文和 英文期刊发表。本文是对旅游需求文献所作的一次最大规模的述评。本文也是首篇 集中研究一个地理区以及涵盖中英文文献的旅游需求评论文章。本文的评论重点包 括研究发展、地理焦点、数据类型和频率、需求弹性分析、预测活动以及研究趋 势。通过比较分析中文和英文文献发现两种语言的文献在许多研究方面都存在差 距, 如研究方法的多样性和复杂性、建构模型和预测过程的严谨程度以及需求分析 的理论基础。本文最后提出相应建议以期进一步推进大中华旅游需求研究的质量。
\end{abstract}

关键词: 大中华, 旅游需求, 预测, 建模, 述评

\footnotetext{
${ }^{1}$ Gang Li is a Senior Lecturer of the School of Management at the University of Surrey, Guildford, GU2 7XH, UK (Email: G.Li@surrey.ac.uk). This is an author-prepared, peer-reviewed PDF of an article published in the Journal of China Tourism Research, 5: 2-40, 2009.
} 


\section{Introduction}

Modelling the effects of various factors on tourism demand and forecasting the future trends are two major focuses of tourism demand studies (Li et al., 2005). The analysis of the effects of tourism demand determinants provides important information for formulating and evaluating tourism policies and strategies. Tourism demand forecasting serves the practitioners in both public and private sectors in a number of ways. Firstly, the success of many tourism businesses such as airlines, hotels and tour operators depends largely on the state of tourism demand. Estimates of expected future demand constitute an important element in their planning activities, particularly given the perishable nature of tourism products. Secondly, tourism investment, especially in a destination's infrastructure, requires long-term financial commitments, and the sunk costs can be very high if the investment projects fail to fulfil their design capacities. Therefore, the prediction of long-term demand for tourism-related infrastructure often forms an important part of project appraisal (Frechtling, 2001). Thirdly, accurate forecasts of the scale and growth of tourism demand in a destination help the government decide on and implement appropriate medium-long term policies in order to achieve the sustainable tourism development.

Asia and the Pacific has been one of the fastest growing tourism regions in the world over the past decade and this trend will continue in the forthcoming decades (World Tourism Organization [UNWTO], 2000). Within this region, Greater China including Mainland China, Hong Kong, Macau and Taiwan contributes most significantly to both regional and global tourism developments. According to the UNWTO (2008), tourist arrivals to Greater China reached 88.5 million in 2007, which accounted for almost half of the total in Asia and the Pacific and nearly one-tenth of the world total tourist flows. In particular, Mainland China is the fourth most popular tourist destination in the world and it is predicted to reach the top by 2020 or even earlier (UNWTO, 2000). In addition to a fast growth of $9.2 \%$ in Mainland China, Macau obtained an even faster growth of $12.5 \%$, and Hong Kong and Taiwan both gained higher than $5 \%$ growth rates, in terms of international tourist arrivals in 2007 against the previous year. Not only has Greater China become one of the most popular tourist destinations, it features as an active source market of international tourism. Mainland China, Hong Kong and Taiwan appeared in the $6^{\text {th }}, 14^{\text {th }}$ and $22^{\text {nd }}$ positions in the world respectively, in terms of tourist spending in 2006.

The socioeconomic significance of the rapid tourism development in Greater China has inspired international scholars' interests in researching the determinants and effects of the increasing tourism demand in this region, and predicting the trends of future demand. According to the author's literature search, more than 200 journal articles have been published since the early 1990s in either English or Chinese language, focusing on modelling and forecasting tourism demand for Greater China. Given the importance of tourism demand research and its rapid growth in this region, it is necessary to provide a comprehensive review of the existing studies. By summarising similarities and 
dissimilarities of past studies in the this field, and identifying the common trends and issues, this review aims to provide guidance to other researchers interested in undertaking similar tasks in the future. It is expected that this overview will encourage further developments of tourism demand studies related to this region.

\section{Literature Review}

Tourism demand modelling and forecasting studies have had a half-a-century history. The earliest work can be traced back to the 1960s, notably pioneered by Guthrie (1961). Since then there have been significant developments in the research of this field, in terms of the diversity of research interests, the depth of theoretical foundations, and advances in research methodologies (Li et al, 2005). In the earlier three decades, research in this field had a predominant focus on Europe and North America. The majority of publications focused on these regions, either as tourist destinations or source markets. This geographic distribution of tourism demand studies was in line with the general trends of global tourism development. Not until the earlier 1990s was the research attention placed on Greater China, in parallel with the phenomenal growth of the tourism industry of this region.

The developments of tourism demand research were reviewed in a number of literature surveys. In earlier reviews such as Archer (1980, 1987), Bar-On (1984) and Vanhove (1980), considerable attention was devoted to explaining the techniques applicable to tourism demand forecasting. More recently Crouch (1994a, 1994b, 1994c, 1994d, 1995, 1996) conducted a series of more comprehensive reviews covering about 80 econometric studies during the period 1961-1993. In particular, Crouch (1994a, 1994b, 1995, 1996) identified various inter-study differences, principally with respect to demand elasticities. Similarly, Lim (1997a, 1997b, 1999) reviewed 100 papers published during the period 1961-1994. Attention was paid to the choice of dependent and explanatory variables, functional specifications and data in use. Witt and Witt (1995) reviewed 40 empirical studies published prior to 1992, with a particular emphasis on empirical comparisons of forecasting accuracy among different approaches. Li et al. (2005) and Song and $\mathrm{Li}$ (2008) reviewed the most recent 84 and 121 tourism demand studies, respectively. They identified the latest methodological developments and emerging trends in this field of research.

All of the above review studies are based on publications in English and without a specific regional focus. Moreover, a large body of the literature in Chinese language has been excluded from the above reviews. Although there have been a few general overviews of tourism demand studies published in Chinese language journals, no comprehensive literature survey has been conducted. The objectives of these studies were to introduce the approaches to tourism demand analysis such as Ouyang and $\mathrm{Hu}$ (2007) and Ren and Liu (2006b), or to share their general observations on issues and problems of current tourism demand studies, such as Dai (2003). Therefore, they only briefly referred to very few empirical studies either in Chinese or in English as examples of the applications of the introduced forecasting techniques. Thus, there has been a gap in the 
literature; that is, no attempt has been made to give a comprehensive review of all tourism demand modelling and forecasting literature focusing on Greater China and published in both Chinese and English languages. This study therefore aims to bridge the gap.

\section{Research Design}

The purpose of this study is to review and evaluate the existing empirical literature on tourism demand studies with a regional focus on Greater China. This study will investigate the similarities and dissimilarities among the empirical studies, summarise the key issues and trends in the literature, and suggest new directions for future research. In particular, since the studies published in both Chinese and English languages are covered in this review, particular attention is paid to the comparison between the two bodies of literature. Common trends and research gaps are to be identified.

In this study, "Greater China" is defined to cover Mainland China, Hong Kong, Macau and Taiwan, in line with the definition of the Journal of China Tourism Research. The term "Greater China" emerged in the early 1990s to account for the growing economic interaction and integration as well as socio-cultural ties between the four areas (Peng et al., 2001). It has been commonly accepted by scholars especially in the fields of economics and investment (e.g., Harding, 1993; Lin and Lin, 2001). It has also appeared in some tourism literature (e.g., Heung and $\mathrm{Qu}, 1998$ ). In the contemporary tourism context, the interaction between the four component areas has been increasing. The gradually extended Individual Visit Scheme allows increasing numbers of Mainland Chinese tourists to visit Hong Kong and Macau since 2003 (Hong Kong Economic and Trade Office, London, 2005). The agreement on direct flights between Mainland China and Taiwan implemented in July 2008 is expected to stimulate more intra-regional travel and tourism activities (Chinadaily, 2008). Tourism authorities of Macau and Hong Kong have been cooperating actively in promoting regional tourism together. Given the increasingly close ties between the four areas, it is most appropriate to regard these areas as a whole in this study.

To serve this review extensive literature search was conducted based on various databases such as the social science citation index (SSCI), Google Scholar, ScienceDirect and EBSCOhost. In addition, the Renmin University's Chinese-Language Literature Database was used to search for Chinese articles published in Mainland China. Due to inaccessibility to Taiwan's local literature databases, no articles published in local journals have been collected. However, many Taiwanese scholars published their studies in international journals. These publications have been obtained through the literature search. The preliminary search was based on various combinations of the key words: tourism demand, modelling, forecasting, China, Hong Kong, Macau, and Taiwan. Secondly, the citations from identified articles were traced. Then among the over 200 identified publications, only empirical studies on tourism demand modelling and/or forecasting with a particular focus on at least one of the four areas of Greater China were finally selected. The literature collection was mostly done in January 2008 and an update 
of the English language literature search was carried out in June 2008. Finally 180 journal articles were collected, including 43 published in English journals (termed hereafter "international studies") during the period 1992 - early 2008, and 137 papers published in Mainland Chinese journals (termed hereafter "Chinese studies") between 1992 and 2007. This study presents the most up-to-date review of the tourism demand modelling and forecasting literature. In terms of the number of articles included in the review, this study is of the largest scale in the research field. In addition, the unique regional focus and the bilingual nature of the literature under review differentiate this study from others.

\section{Results and Discussion}

The full details of the 43 international studies and 137 Chinese studies are provided in Tables 1 and 2, respectively. The review is therefore based on the 180 studies and the emphasis is placed on the following issues: research development, geographic focus, data type and frequency, measurement of tourism demand, modelling and forecasting techniques, demand elasticity analysis, forecasting exercises and emerging research trends. The findings of this review in these aspects are summarised and discussed below.

\{Insert Table 1 about here\}

\{Insert Table 2 about here\}

\section{Research Development}

With regard to the development of tourism research related to Greater China, two distinctive time patterns can be identified between the international and Chinese studies (see Figure 1). Tourism demand studies in Mainland China have been growing at accelerating speed over the observation period (1992-2007). The whole period can be divided into three phases: 1992-1999: exploring; 2000-2003: involving; and 2004 onwards: accelerating, according to the number of studies published each year. Overall, the development of tourism demand research in Mainland China is still in its early stage. Both the quantity and quality are to be developed further. In comparison, the growth of international studies on Greater China's tourism demand shows a highly stable pattern. As a new phenomenon and emerging market, Greater China will attract increasing attention of international scholars in the following decades.

\{Insert Fig. 1 about here\}

\section{Geographic Focus}

As Table 3 shows, Hong Kong has attracted overwhelming attention among international studies, followed by Mainland China and Taiwan, all being researched mainly as international tourist destinations. Although both domestic tourism and outbound tourism have developed fast in Mainland China in recent years, only two studies (Cai and Knutson, 1998; Cai et al., 2002) investigated the domestic tourism and one ( $\mathrm{Qu}$ and Lam, 1997) examined outbound tourism to Hong Kong. Song and Witt 
(2006) is the only study that examined tourism demand in Macau. A few studies included more than one area of Greater China. The popularity of international tourism research on Hong Kong can be explained by its long history of tourism development. With respect to the studies on Mainland China and Taiwan, their limited data availability has restricted the research development. In particular, the data of Mainland China's outbound tourism demand are not disclosed by the Chinese authority in the public domain. To carry out such research one would have to rely on the statistics provided by the destination countries or regions of Chinese outbound tourists. However, such data could not support a study on the aggregate demand for outbound tourism.

\{Insert Table 3 about here\}

The Chinese studies spread their geographic focuses among national, regional/provincial, and city/town levels, as well as particular scenic sports. Given the economic significance in terms of foreign exchange earnings, more than half of the studies investigated and predicted the demand by international markets (see Table 3 ). In particular, Japan and the USA are the most frequently researched short-haul and longhaul markets respectively. Due to data unavailability as discussed above, the same research gap is observed among Chinese studies regarding Mainland China's outbound tourism.

\section{Data Type and Frequency}

Almost all of the reviewed studies employed time-series data, with only seven exceptions among the Chinese studies which used cross-sectional data. Where time series data were employed, the annual frequency has dominated both Chinese and international studies ( $82 \%$ and $60 \%$, respectively). Compared with the findings of previous reviews, the common trend is that annual data have been the most popular data frequency for tourism demand studies. However, the new tendency identified in the general tourism demand literature regarding the increasing popularity of quarterly data (see Li et al., 2005) is not shown in this review. The use of seasonal data is often associated with seasonality analysis of tourism demand. However, among all the reviewed studies related to Greater China, few have paid particular attention to this issue (with Kulendran and Shan (2002) being an exception). Seasonal patterns of tourism demand and their potential changes over time, the treatment of seasonality (i.e., stochastic versus deterministic seasonality) in tourism demand models and its impact on the forecasting accuracy have been largely ignored in these studies.

In addition to the above mentioned data frequencies, some less commonly used frequencies are identified among the Chinese studies. For example, Wang (2004) and Zhang and Chen (2007) used the data at semi-annual frequencies, and Ge and Hua (2006), Zhao et al. (2006) and Wang and Hua (2006) employed daily data. These special data frequencies are usually associated with special events such as the Canton Trade Fair and national golden-week holidays in Mainland China.

\section{Measurement of Tourism Demand}


In consistency with the general literature on tourism demand modelling and forecasting, tourism demand for Greater China is usually measured by the number of tourist arrivals and tourist expenditure, with the former being more popular. In a few cases the per capita forms of these measures were used too. Among the Chinese studies $72 \%$ measured tourism demand by tourist arrivals, $14 \%$ by tourist expenditure (or tourism receipts), and $14 \%$ by both. As for the international studies, $80 \%$ and $16 \%$ employed tourist arrivals and tourist expenditure, respectively. In addition, two studies used both measures. The choice of tourism demand measures is mainly driven by the ease of data accessibility, while the purpose of tourism demand studies should also be taken into account. Tourist volumes are important for tourism service suppliers such as hotels, airlines and visitor attractions, because the volume has direct relevance to capacity management. Tourist expenditure (i.e., the receipts of the tourism industry in a destination) is the main concern of governments and central banks because it is the foundation on which the economic impact of tourism activities is assessed and tourism policies are made. Furthermore, different evolution patterns in tourist arrivals and expenditure time series emerge for most destination/origin country pairs. This has been observed by scholars such as Sheldon (1993) and García-Ferrer and Queralt (1997) in their empirical studies on OECD countries and Spain, respectively. However, no studies related to Greater China have been identified to pay attention to the comparison between these two demand measures, or the relationship between the choice of demand measures and the accuracy of demand forecasts.

Among the seven tourist expenditure studies, Au and Law (2000), Au and Law (2002), Cheung and Law (2001) and Law and Au (2000) examined the sub-sector level of tourist spending on sightseeing, dinning, accommodation and shopping, respectively. Besides tourist arrivals and tourist expenditure, the hotel occupancy rate was used in three studies to measure the demand for tourist accommodation. The use of disaggregated data (at the sub-sector or even lower levels) enables scholars to give more insights into these tourism businesses, and draw more specific managerial implications, which are useful for the business operations in the related sub-sectors.

\section{Modelling and Forecasting Techniques}

Modelling and forecasting techniques for tourism demand studies have experienced substantial developments. Tourism demand forecasting methods are commonly divided into two categories: quantitative and qualitative methods (Song and Li, 2008; Ren and Liu, 2006b; Witt and Witt, 1995). The majority of published studies in the general tourism forecasting literature used quantitative methods (Song and Turner, 2006). The quantitative forecasting literature has been dominated by causal econometric approaches and non-causal time series models, while some artificial intelligence techniques begin to appear in recent tourism forecasting studies. These trends in the general tourism forecasting literature are also reflected in the studies on Greater China's tourism demand.

Time-series Methods. Eleven time-series forecasting techniques were applied in 17 international studies and 84 Chinese studies. The autoregressive integrated moving 
average (ARIMA) model and its seasonal version (i.e., SARIMA model) were used most often among the international studies. This trend is in line with the general tourism forecasting literature (Song and Li, 2008). Since the ARIMA model was initially proposed by Box and Jenkins (1970), researchers have put great effort into its further developments. The applications of these new developments have been seen in some studies. For example, Goh and Law (2002) introduced a multivariate SARIMA (i.e., MARIMA) model which includes an intervention function to capture the potential spillover effects of the "parallel" demand series on a particular tourism demand series. Their study showed that the MARIMA model significantly improved the forecasting performance of the simple SARIMA as well as other univariate time series models. In another Chinese study, Lei and Chen (2007) combined the ARIMA model with a neural network method. They predicted the linear trend of a tourism demand series using the ARIMA model, and then used the neural network method to forecast the non-linear element of the series that was maintained in the residuals of the ARIMA model. Subsequently, the two parts of predictions were combined to obtain the final forecasts. This combined method showed improved forecast accuracy compared to both component methods.

Other modern and advanced time-series approaches such as the basic structural time series model (BSM) and the generalised autoregressive conditional heteroscadesticity (GARCH) model have been applied in both international and Chinese studies (e.g., Kulendran and Shan, 2002 and Shang and Qin, 2007, respectively), although such applications are still limited. A BSM is based on the identification of unobserved components (including trend, cyclical, seasonal and irregular components) which are directly interpretable out of the data. Then these components are modelled in a state space form and estimated by a powerful recursive algorithm known as the Kalman filter (see Harvey (1989) for technical details). The stochastic treatment of the unobserved components such as seasonality is more in line with the actual data properties, and thus the BSM generally provides sound forecasting performance. The family of GARCH models have been widely used in financial modelling. It was introduced into the tourism context recently to investigate the volatility of a demand series and examine the effects of various shocks to a tourism demand system. Shang and Qin (2007) presented the first attempt to successfully apply a GARCH model to tourism demand forecasting. Naïve 1 (i.e., no-change) and naïve 2 (i.e., constant-growth-rate), autoregressive (AR), moving average (MA) and exponential smoothing (ES) models are often used as benchmarks in forecast accuracy comparison studies. Trend extrapolation models (TEMs) in either linear or non-linear forms dominate the Chinese studies on time-series forecasting, with 63 applications being identified. In a TEM, a tourism demand series is regressed against the deterministic time trend, and the selection of the functional forms (linear or nonlinear) is based on trials without any scientific criteria or diagnostic tests. Such a basic regression is unable to cope with business cycles and irregular shocks to the system, and its mediumto long-term forecasts could be seriously misleading (Che, 2004).

Econometric Models. Different from time-series models, econometric approaches include various influencing factors of tourism demand as the independent variables in their model specifications. Nine econometric forecasting methods have been applied in 
more than $50 \%$ of the international studies but in only $20 \%$ of Chinese studies. These econometric models include the autoregressive distributed lag model (ADLM, with the error correction model and static regression model as its specific forms), the ARIMA model augmented with causal variables (ARIMX), cointegration (CI) model, gravity model (GraM), panel data regression (PDR) model, simultaneous equation model (SEM), structural time series model with causal variables (STSM), time varying parameter (TVP) model and vector autoregressive (VAR) model. Two traditional static econometric models: static regression and gravity model, dominate the 27 Chinese studies, while no applications of the advanced econometric models such as ECM, VAR and TVP models have been identified among the Chinese studies. The static models suffer from a number of problems. Firstly, they omit the dynamics of a demand system. In other words, they ignore the "word of mouth" effect or habit persistence of tourism demand (Song and Witt, 2000). Secondly, as we know, tourism demand is not only affected by the current status of economic variables such as income and prices, but also their changes in previous months and years. However, these effects can not be captured by a static econometric model. Thirdly, the stationarity property of the variables is not detected in a static model. As a result, the spurious regression problem is likely to occur (Song and Witt, 2000). Moreover, the often used static model specification - the gravity model — lacks a strong theoretical underpinning, which leads to the ad hoc choice of explanatory variables (Che, 2004). The reliability of the estimation results of such a model is questionable.

Among the 23 international studies, there is no dominant econometric approach. Most of the advanced and dynamic forecasting techniques such as the TVP model and the STSM have been employed in these studies. Both models are written in the state space form and estimated by the Kalman filter algorithm. As with the BSM, the STSM is useful to model seasonal tourism demand. In addition, inclusion of explanatory variables in a modelling process gives the STSM more explanatory power. The TVP model is often used in conjunction with annual data. Its unique power is on the analysis of tourism demand elasticity evolution. Both the TVP model and the STSM have shown superior performances especially for short-term forecasting. Different from most Chinese econometric studies, all international studies reported necessary diagnostic test results (e.g., nonnormality, heteroscadesticity, autocorrelation, misspecification and forecasting failure) in addition to the commonly reported model fit indicators such as $R$-squares and $F$-statistics. These models that passed all or most of the diagnostic tests are therefore more reliable for subsequent demand analyses and forecasting. However, the diagnostic tests were rarely reported in the Chinese studies. Without good knowledge of the properties of the reported models, it is highly risky to rely on their estimates for policy making or business strategy projection.

In line with the general tourism demand literature, the most commonly considered influencing factors of Greater China's tourism demand (both inbound and outbound) are tourist income, tourism prices in the destination, and one-off events such as the Asian financial crisis in 1997, the SARS epidemic in 2003 and the bird flu in 2005. Tourism prices are often measured in a relative term, i.e., tourism prices in a destination relative to those in the source market concerned, adjusted by the relevant exchange rates. In addition, exchange rates are often used especially in the Chinese studies to measure tourism prices. 
Although some earlier literature (e.g., Sinclair and Stabler, 1997) suggested the appropriateness of using the exchange rate variable as a proxy of tourism prices, the relative form of tourism prices adjusted by exchange rates takes multiple factors of tourism prices into account and has been more popular in recent international studies.

Artificial intelligence (AI) techniques. The AI technology, as a third branch of forecasting methodologies, has been recently introduced into the tourism demand forecasting literature. The often used AI techniques for forecasting include neural networks, rough sets, genetic algorithm, support vector regression, fuzzy logic, grey theory and their combinations (Goh, et al, 2008a; Toshinori, 1998). They can be used as either causal or non-causal forecasting methods, depending on whether any influencing factors of tourism demand are considered. These methods including the combination of the genetic algorithm and the support vector regression have all been applied in the reviewed studies, including 12 international studies and 41 Chinese studies. The grey model is employed most often (particularly among the Chinese studies, with 31 applications), followed by various neural network methods. The merit of AI forecasting techniques is to relax data property requirements such as stationarity and normal distribution. Empirical evidence has shown their sound forecasting accuracy in comparison to their traditional counterparts. However, without a theoretical foundation in social sciences such as economics, it is difficult to interpret the results of these techniques from the economic perspective.

Other Forecasting techniques. Among the Chinese studies some mathematical models that are often used in physics (e.g., Markoff chain) or control engineering (e.g. Hammerstein model) have been introduced into the tourism context for ex ante forecasting, such as Zhang (2000) and Zhang and Wang (2002), respectively. However, little justification was provided to explain why and how these models were appropriate to study tourism demand. Moreover, it is necessary to exercise a forecasting competition against other well-performing techniques in order to prove these models' superior predictive power.

A few international and Chinese studies applied multiple forecasting approaches across time-series, econometrics and AI categories. The main purpose is to compare their forecasting performances. This is to be discussed in a later section.

\section{Demand Elasticity Analysis}

Elasticity analysis has its theoretical foundation on demand theory and interprets tourism demand from the economic perspective. Tourism demand elasticities have been discussed extensively in the general tourism literature and some common issues have been summarised in previous review studies such as Crouch (1992, 1994a, 994b, 1995, 1996). However, only a few international studies showed interests into the research in this area, and no Chinese studies have discussed demand elasticities at all. The lack of interest in elasticity analysis among Chinese studies is associated with the unpopularity of the econometric methodology (especially at the advanced level, using CI and ECM approaches for example). Based on the available empirical evidence, some general 
findings of tourism demand elasticity analysis are summarised (see Table 4). Consistent with most findings in the general tourism demand literature, international tourism demanded for and by Greater China, including the intra-regional tourism, is generally regarded as a luxury product (i.e., the income elasticity is greater than one), as opposed to the domestic tourism (such as that in Mainland China), which features a necessary product (i.e., the income elasticity is lower than one). In particular, where Hong Kong was studied as an international tourism destination, the average income elasticity across various source markets was consistently estimated as around 2 . The implication is that once the tourists' income increased by $10 \%$, their demand for tourism in Hong Kong would be likely to increase by about $20 \%$. This finding suggests that the tourism industry in Hong Kong should closely monitor the economic situations of the key source markets and respond effectively to the changes of their economic status.

\section{\{Insert Table 4 about here\}}

With respect to the price elasticity of tourism demand, the findings based on Greater China are in line with economic theory, that is, an increase in tourism prices in a destination would lead to a decrease in the demand for this destination. In other words, the price elasticity of tourism demand is negative. However, the magnitudes of the price elasticity vary considerably across studies even on the same region. The discrepancy is due to the econometric models adopted and the sample period covered. As discussed above, the evolution of income and price elasticities can be analysed using the TVP model. For example, based on this model Song and Wong (2003) found that the income elasticity of demand for tourism in Hong Kong decreased over time as far as the UK and USA were concerned. The implication is that travelling to Hong Kong has become less and less luxurious for British and American tourists. With regard to the price elasticity, fluctuations were observed in most source markets, especially during oil crises and the world economic depression in the late 1970s. A few studies also examined the cross-price elasticity of tourism demand, but it often appeared insignificant (e.g., Song and Fei, 2007; Song et al, 2003). The insignificant substitution effect partially reflects the unique characteristics of the destinations under study and their relatively high competitiveness.

\section{Forecasting Exercises}

Four different types of forecasting exercises appeared in $75 \%$ of international studies and $85 \%$ of Chinese studies. These exercises are: (1) ex post forecasting, that is, examining the out-of-sample forecast accuracy of a tourism demand model (Song and Witt, 2000); (2) forecasting competition, that is, comparing alternative forecasting techniques' ex post forecast accuracy; (3) ex ante forecasting, that is, generating forecasts of future demand; (4) combining the forecasts generated by individual techniques, for which a number of combination methods can be exercised. It should be noted that ex post forecasting is different from the within-sample "prediction". The latter is not regarded as real forecasting, but an examination of the model fit to the data in use. To evaluate forecasting accuracy properly, ex post forecasting must be conducted. This requires withholding some data at the end of the historical series and using these data to compare with the out-of-sample forecasts. 
International Forecasting Studies. Distinctive trends on forecasting exercises are identified between the two bodies of literature (see Table 5). Among the international studies, the most exercised forecasting practice was forecasting competition, which accounts for more than half of the forecasting studies. The objectives of these studies were to introduce new techniques into tourism forecasting research and examine their forecast accuracy in comparison to other approaches. Certain attention was also paid to both ex post forecasting and ex ante forecasting, but without an attempt to compare different forecasting techniques. Once ex ante forecasts were to be generated, ex post forecast evaluation was always performed first to justify the robustness of ex ante forecasting results.

\section{$\{$ Insert Table 5 about here $\}$}

Chinese Forecasting Studies. Ex ante forecasting dominated Chinese forecasting studies, and very little attention was given to forecasting competition or ex post forecasting. Among the 101 ex ante forecasting studies, a large proportion reported within-sample "predictive" errors (i.e., residuals of model fit) only, and only 20 of them performed ex post forecast evaluation. Another issue is the extremely short historical time series to construct the forecasting model in contrast to the very long forecasting horizons. Although there has not been a commonly agreed guidance in the forecasting literature regarding the ratio between the number of historical data and that of reliable forecasts that can be generated, some scholars suggest a minimum of 5:1 as a rule of thump (Frechtling, 2001). However, in a number of the Chinese studies under review, this ratio is lower than 1:1. Although this ratio may vary between different forecasting methods (for example, a grey model requires less historical data then traditional models), it is always necessary to conduct diagnostic tests for the forecasting model and evaluate ex post forecast accuracy prior to ex ante forecasting. Only the model that has passed all or most diagnostic tests and shown acceptable ex post forecast accuracy should be used for ex ante forecasting.

Best Performing Forecasting Method. In spite of different interests into tourism forecasting exercises between international and Chinese studies, some common trends have been identified. With regard to forecasting competition, no single forecasting technique could outperform the others on all occasions. This finding is in line with the general literature reviews (e.g., Li et al., 2005). AI techniques have attracted increasing interests among more recent studies. In particular, neural networks and grey models often outperform other traditional time-series methods (e.g., MA, ES, naïve 1 and 2 models), but no attempt has been made to compare the forecasting performance between the newly developed AI techniques and the advanced econometric approaches (e.g. TVP model, ECM and STSM). To fulfil this task, collaboration among researchers with different technical expertise is necessary.

Forecast Combination. Since no single forecasting technique can always outperform others, there have been some attempts in recent tourism forecasting literature to combine individual forecasts. Three Chinese studies (Li, 2001; Zheng and Liu, 2001; 
Zhou and Liu, 1996) and one international study (Wong et al, 2007) have exercised forecast combination using three different methods: single average, variance-covariance and discounted mean square forecast error methods, and they commonly showed favourable results. Different from the three Chinese studies, Wong et al. (2007) included three advanced econometric models (ECM, VAR and ADLM) along with ARIMA into the combination exercise. Even in the general tourism forecasting literature, very few studies have examined this issue. Further research should explore the potential of more accurate forecasts by employing new combination techniques such as nonlinear methods.

Integration between quantitative and qualitative forecasting. In addition to the quantitative ex ante forecasting, one study (Guan et al., 1998) conducted judgemental forecasting using the Delphi method, which was based on a structured process for collecting knowledge from a group of experts by means of a series of questionnaires. In general, quantitative forecasting is more suitable for short-term demand prediction, while for medium to long-term projections, qualitative approaches should be considered (Uysal and Cromption, 1985). The integration of quantitative and qualitative forecasts reduces the risk of forecasting failure and provides more reliable information for decision makers. However, such attempts are often ignored in tourism forecasting practice.

\section{Emerging Research Trends}

Greater China as one of the emerging markets of international tourism has presented its unique characteristics, as either a source market or a destination region. Correspondingly, tourism demand research related to this region shows some distinctive emphases. A certain degree of heterogeneity within this market further leads to divergent research trends in Hong Kong, Taiwan and Mainland China. ${ }^{2}$ For example, Hong Kong is always researched as an international tourism destination. Moreover, due to better data quality and availability, tourism demand research has been extended from the industry aggregate level to the sub-sector level, with a particular emphasis on the hotel sector (e.g., Law, 1998 and 2004; Qu et al., 2002; Tse, 2001). With respect to Taiwan, given its relatively small scale and fragile nature of the tourism industry, a number of studies assessed the impacts of disasters and crises (such as the earthquake, SARS and bird flu) on its inbound tourism demand (e.g., Huang and Min, 2002; Min, 2005). Mainland China has the richest tourism resources, and attracts the most diverse research interests. Unlike other regions either within or beyond Greater China, domestic tourism in Mainland China has attracted a great deal of research attention. In addition, inbound tourism demand studies have been extended from the national level to provincial and cities levels (e.g., Bian and Song, 2007; Chen and Zhang, 2007; Gao, 2002). Particular attention has been given to the demand for individual scenic sports (e.g., Liu et al., 2007; Lu et al., 2002; Peng and Qu, 2003) and participation in mega events such as Shanghai World Expo 2010 (Feng, 2004) and the Canton Trade Fair (Zhang and Chen, 2007). Moreover, analysis of tourism cycles has become increasingly popular (e.g., Li, 2003; Sun, 2001; Xie, 2007; Zhang and Lu, 2004).

\footnotetext{
${ }^{2}$ Macau is excluded from the discussion on research trends because there has been only one study focusing on this region and therefore no trends could be summarised.
} 


\section{Concluding Remarks}

By comprehensively reviewing 180 empirical studies related to Greater China's tourism demand modelling and forecasting, this study acts as a useful guide and convenient reference for other scholars who are interested in conducting similar research on this region.

It is found that tourism demand research about Greater China shares some similar trends and characteristics to the studies about other regions such as Witt and Witt (1995), Li et al. (2005) and Song and Li (2008), in terms of the measurement of tourism demand, data frequency, findings of demand elasticity analysis and lack of consistently topperforming forecasting techniques. For instance, both Witt and Witt (1995) and Li et al. (2005) concluded from their reviews that there was no single forecasting technique that outperformed the others on all occasions.

Within this region, Hong Kong, Taiwan and Mainland China have received divergent research interests. Hong Kong has always been studied as an international destination, and increasing attention has been paid to the tourism demand at sub-sector level, particularly for the hotel sector. The effects of disasters and crises have been topical issues of Taiwan's tourism demand studies. The development of tourism demand research in Mainland China has been phenomenal over the past 25 years. Diverse research interests and new research methods especially AI techniques have been explored. However, the comparison between these Chinese studies and those at the international level reveals a number of gaps, such as the diversity and sophistication of the research methodology, rigour of the modelling and forecasting process and the theoretical foundation of demand analysis. To bridge the research gap, the following aspects warrant more attention of Mainland China's tourism demand studies:

- Application of modern and advanced econometric modelling approaches to both demand elasticity analysis and forecasting;

- Diagnostic tests on the demand model to be applied for policy evaluation or forecasting;

- Ex post forecast evaluation to be performed prior to ex ante forecasting;

- Caution to be exercised when short historical series are used for medium and longterm forecasting.

In addition, some new directions of tourism demand studies on Greater China are identified:

Tourism Seasonality Analysis. Tourism in most destinations presents seasonal variations, and Greater China is not an exception. However, as an emerging market undergoing fast growth, Greater China, especially Mainland China, is most likely to experience changing seasonal patterns. In other words, seasonality in this region should be treated as stochastic rather than deterministic in tourism demand analysis. Such a more appropriate treatment of seasonality in a demand model is likely to lead to the enhanced 
performance of seasonal tourism demand forecasting. Research in this direction is worth exploring.

Outbound Tourism Demand Analysis. Extremely few studies have investigated outbound tourism demand from Greater China. Travelling abroad is a new phenomenon especially as far as Mainland Chinese tourists are concerned. Their unique travel behaviour, travel decision making and the impacts of their travel activities on both a destination and their home country/region are all interesting topics for future tourism demand research. Given the data unavailability at the aggregate level, a feasible direction is to examine the outbound tourism demand for individual destinations where the data of China's inbound tourism demand are available.

Turning Point and Directional Change Forecasting, Forecast Combination and Forecast Integration. Tourism practitioners are interested in not only the overall trend of tourism demand, but more importantly the timing of the directional change in tourism growth. This knowledge has important implications on effective business planning and macroeconomic policy making (Song and Li, 2008). Despite the practical importance, there has been limited literature focusing on this issue, even among the general tourism demand literature. To enhance the practical value of forecasting exercises, future forecasting studies on Greater China should focus on not only point forecasting, but also turning point and directional change forecasting. Meanwhile, although there have been a few attempts to combine individual forecasts and to integrate quantitative forecasts with judgemental forecasts, some research gaps are still to be bridged. For example, econometric forecasting and AI prediction have been two isolated research areas. The potential of forecast accuracy improvements should be explored through their combination. Moreover, some AI techniques such as the NN method can act as not only a forecasting technique, but a nonlinear combination approach. No empirical studies have investigated the effects of nonlinear combination in the tourism context. When mediumand long-term projections are concerned, judgemental forecasting should be performed to assist or adjust the quantitative perdition. 


\section{References}

Archer, B. H. (1980). Forecasting demand: Quantitative and intuitive techniques. International Journal of Tourism Management, 1 (1), 5-12.

Archer, B. H. (1987). Demand forecasting and estimation. In J. R. B. Ritchie, \& C. R. Goeldner, (Eds.), Travel, Tourism and Hospitality Research (77-85). New York: Wiley.

Athiyaman, A., \& Robertson, R. W. (1992). Time series forecasting techniques: Shortterm planning in tourism. International Journal of Contemporary Hospitality Management, 4(4), 8-11.

Au, N., \& Law, R. (2000). The application of rough sets to sightseeing expenditures. Journal of Travel Research, 39(1), 70-77.

Au, N., \& Law, R. (2002). Categorical classification of tourism dining. Annals of Tourism Research, 29(3), 819-833.

Bai, J. F., \& Wu, B. F. (2003). Analysis and forecasting of China's inbound tourism market. Journal of Nanyang Teachers' College, 2(9), 69-71. 白景锋, 吴邦藩 (2003)。中国境外旅游市场的分析和趋势预测研究。南阳师范学院学报, 2(9), 69-71。

Bao, J. G. (1992). An application of gravity model to tourism forecasting. Journal of Zhongshan University, 31(4), 133-136. 保继刚(1992)。引力模型在游客预测中 的应用。中山大学学报, 31(4), 133-136。

Bar-On, R.R.V. (1984). Forecasting tourism and travel series. Problems of Tourism, 3, 24-39.

Bian, Y. Y., \& Song, N. P. (2007). Tentative analysis on the source markets of Ningxia tourism. Ningxia Engineering Technology，6(2)，190-193. 市芗芗，宋乃平 (2007)。宁夏旅游客源市场的初步分析。宁夏工程技术，6(2)，190-193。

Box, G. E. P., \& Jenkins, G. M. (1970). Time Series Analysis, Forecasting and Control. San Francisco: Holden Day.

$\mathrm{Bu}, \mathrm{F}$. J. (2004). Analysis and forecasting of the tourism area life cycle of Nanwan scenic spot in Xinyang. Journal of Xinyang Normal University, 17(4), 459-461. 卜付军 (2004)。信阳南湾风景区旅游地生命周期分析及预测。信阳师范学院学报, $17(4), 459-461$ 。

Bu, F. J., \& Zhao, H. L. (2005). Analysis of economic benefits of tourism at Nanwan scenic spot in Xinyang. Journal of Xinyang Normal University, 18(4), 423-426. 卜付军, 赵红玲(2005)。信阳南湾风景区旅游经济效益分析。信阳师范学院 学报, 18(4), 423-426。

Cai, L. A., \& Knutson, B. J. (1998). Analyzing domestic tourism demand in China-A behavioral model. Journal of Hospitality \&Leisure Marketing, 5(2/3), 95-113.

Cai, L. A., Hu, B., \& Feng, R. (2002). Domestic tourism demand in China's urban centres: Empirical analyses and marketing implications. Journal of Vacation Marketing, $8(1), 64-74$. 
Cai, M. L. (2006). An analysis on the life cycle of the Nanyue scenic spot. Economic Geography, 26(3), 541-544. 蔡梅良(2006)。南岳景区生命周期的分析与调 控。经济地理, 26(3), 541-544。

Cai, M. L., \& Wang, L. J. (2006). A comparative study and forecasting of tourist markets of Nanyue scenic spot. Market Modernization, 469, 220-222. 蔡梅良, 王良健 (2006)。南岳旅游地客源预测模型及其对比研究。商场现代化, 469, 220222 。

Cao, H., \& Chen, Q. H. (2005). A study of tourism demand forecasting models for ecotourism destinations-An example of China Forest Park in Fuzhou city. Technology Economy, 12, 84-86. 曹辉, 陈秋华(2005)。生态旅游景区游客量 预测模型研究——以福州国家森林公园为例。技术经济，12,84-86。

Cao, X., \& Chang, Y. C. (2006). A study of B2J method on tourist flow prediction. Tourism Science, 20(1), 39-44. 曹霞, 常玉春(2006)。上海旅游客流的B - J 方法 预测研究。旅游科学, 20(1), 39-44。

Che, Y. B. (2004). An approach to modeling regional tourist attraction. Resource Development \& Market, 20(3), 163-165. 车裕斌(2004)。区域旅游系统吸引力 模型研究。资源开发与市场，20(3)，163-165。

Che, Y. B., \& Huang, W. Y. (2003). An approach to forecasting the attraction of regional tourism systems-A case study of the southeast region of Hubei Province. World Regional Studies, 12(4), 58-64. 车裕斌，黄晚意(2003)。区域旅游系统吸引力 预测研究—以鄂东南地区旅游系统为例。世界地理研究, 12(4), 58-64。

Chen, C. (2007). Forecasting the trend of Taiwanese tourists in Fujian Province and analysis of its characteristics based on a grey-forecasting model. Shantou University Journal, 23(4), 37-41。陈超(2007)。台湾入闽旅游市场趋势预测。 汕头大学学报, 23(4), 37-41。

Chen, J. (2002). Forecasting international tourism development in Lantsang- Mekong Hypo region. Research on Economic Problems, 4, 120-124. 陈俊(2002)。澜沧 江一涺公河次区域国家国际旅游发展前景的预测分析。经济问题探索，4, 120-124。

Chen, J., Chen, Z. X., Xing, L., \& Fu, X. D. (2005). Forecasting Yunnan's international tourism demand based on the BP neural network method. Journal of Kunming Teachers College, 27(4), 89-91. 陈俊, 陈兆雄, 幸林, 付学德(2005)。基于BP神 经网络的云南国际旅游需求预测。昆明师范高等专科学校学报, 27(4), 8991 。

Chen, K. Y., \& Wang, C. H. (2007). Support vector regression with genetic algorithms in forecasting tourism demand. Tourism Management, 28(1), 215-226.

Chen, L. R., Su, Q., \& Zhang, S. P. (2007). An analysis and forecasting of the tourist market in Tunxi area of Huangshan city. Ecology Environment \& Tourism Development, 24(2), 124-128. 陈丽荣, 苏勤, 张淑萍(2007)。黄山市屯溪区旅游 客源市场分析及预测。生态环境与旅游开发, 24(2), 124-128。 
Chen, P., \& Zhang, Y. H. (2007). An analysis of market features and development directions of inbound tourism in Chongqing since 1997. Journal of Chongqing Technology Business University, 17(3), 49-51. 陈萍, 张玉红(2007)。重庆直辖十 年入境旅游市场特征分析及趋势预测。重庆工商大学学报, 17(3), 49-51。

Chen, R. (2006). Forecasting tourism demand in Xi'an city. China Science and Technology Information, 15, 207-209. 陈睿(2006)。西安市旅游市场需求预 测。中国科技信息, 15, 207-209。

Chen, Y. L., Liu, P. L., Wang, L. J., \& Xu, C. J. (2005). A study of the cycles of China's tourism industry based on the spectral analysis. Hunan Social Science, 2, 104-107. 陈友龙, 刘沛林, 王良健, 许抄军(2005)。基于谱分析方法的中国旅游业波 动周期研究。湖南社会科学, 2, 104-107。

Chen, Y. Y. (2007). Research on the trends of the inbound tourism market in Henan. Journal of Northwest A\&F University, 7(3), 100-104. 陈玉英(2007)。河南省入 境旅游市场发展规律与趋势分析。西北农林科技大学学报，7(3),100-104。

Cheung, C., \& Law, R. (2001). Determinants of tourism hotel expenditure in Hong Kong. International Journal of Contemporary Hospitality Management, 13(3), 151-158.

Chinadaily (2008). Beijing, Taipei agree on direct weekend flights. 13 June, 2008. [Accessed on 28 October 2008]. URL: http://www.chinadaily.com.cn/china/200806/13/content 6759638.htm

Cho, V. (2001). Tourism forecasting and its relationship with leading economic indicators. Journal of Hospitality \& Tourism Research, 25(4), 399-420.

Cho, V. (2003). A comparison of three different approaches to tourist arrival forecasting. Tourism Management, 24(3), 323-330.

Crouch, G. I. (1992). Effect of income and price on international tourism. Annals of Tourism Research, 19, 643-64.

Crouch, G. I. (1994a). Demand elasticities for short-haul versus long-haul tourism. Journal of Travel Research, 33, 2-7.

Crouch, G. I. (1994b). Price elasticities in international tourism. Hospitality Research Journal, 17, 27-39.

Crouch, G. I. (1994c). The study of international tourism demand: A review of findings. Journal of Travel Research, 33, 12-23.

Crouch, G. I. (1994d). The study of international tourism demand: A survey of practice. Journal of Travel Research, 33, 41-54.

Crouch, G. I. (1995). A meta-analysis of tourism demand. Annals of Tourism Research, 22, 103-18.

Crouch, G. I. (1996). Demand elasticities in international marketing: A meta-analytical application to tourism. Journal of Business Research, 36, 117-36.

Dai, X. F. (2003). Some views of statistical analysis on tourism planning. Tourism Tribune, 18(3), 10-13. 戴学锋(2003)。对旅游规划中统计分析的一些看法。旅 游学刊, 18(3), 10-13。

Deng, Z. T., \& Lu, Y. Q. (2006). An application of the BP neural network method to China's inbound tourism forecasting. Tourism Science, 20(4), 49-53. 邓祖涛, 陆 
玉麒(2006)。BP神经网络在我国入境旅游人数预测中的应用。旅游科学, 20(4), 49-53。

Dong, X., \& Fang, X. H. (2006). The pull effect of the "Red Tourism" on tourist amount in relatively mature destinations - An example of Mount Wuyi. Journal of Beijing International Studies University, 3, 12-16. 董霞, 方旭红(2006)。“红色旅游”对 相对成熟旅游地客流量的拉升作用——以武夷山为例。北京第二外国语学院 学报, 3, 12-16。

Fan, M. H. (2004). An application of statistics methods to tourism forecasting. Inner Mongolia Sci-Tech \& Economy, 15, 137-138. 范明华(2004)。统计方法在旅游 数据预测中的应用。内蒙古科技与经济, 15, 137-138。

Feng, X. G. (2004). Forecasting the number of visitors to the World Expo Shanghai 2010 from the Changiiang Delta and the corresponding strategies. Shanghai Economics Research, 8, 35-41. 冯学钢(2004)。2010年上海世博会长三角地区参观人数的 预测及应对策略。上海经济研究, 8, 35-41。

Frechtling, D. C. (2001). Forecasting Tourism Demand: Methods and Strategies. Oxford: Butterworth-Heinemann.

Gao, J. H. (2002). Forecasting inbound tourism demand in Xi'an city. Statistics and Decision, 11, 41. 蒿建华 $(2002)$ 。西安市入境旅游规模预测。统计与决策, 11 , 41 。

García-Ferrer, A., \& Queralt, R. (1997). A note on forecasting international tourism demand in Spain. International Journal of Forecasting, 13, 539-549.

Ge, J. H., \& Hua, C. C. (2006). An application of the grey model of translation sequences to tourism forecasting in the National-Day Golden Week. Journal of Yunnan University, 28(S1), 61-64. 葛菊红, 化存才 (2006)。“平移序列”的灰色预测模型 及其在国庆黄金周中的应用。云南大学学报，28(S1)，61-64。

Goh, C. Mok, H. M. K., \& Law, R. (2008a). Artificial intelligence applications in tourism, in M. Khosrow-Pour (Ed.) Encyclopedia of Information Science and Technology, 2nd Edition. Hershey, USA: Information Science Reference.

Goh, C., \& Law, R. (2002). Modeling and forecasting tourism demand for arrivals with stochastic nonstationary seasonality and intervention. Tourism Management, 23(5), 499-510.

Goh, C., \& Law, R. (2003). Incorporating the rough sets theory into travel demand analysis. Tourism Management, 24(5), 511-517.

Goh, C., Law, R., \& Mok, H. M. K. (2008b). Analyzing and forecasting tourism demand: A rough sets approach. Journal of Travel Research, 46, 327-338.

Gou, X. D., \& Sun, G. N. (2000). Foundation and application of the background-trendline to inbound tourism in Shanghai. Journal of Shaanxi Normal University, 28(2), 110-114. 荷小东，孙根年(2000)。上海市入境旅游本底趋势线的建立及其应 用。陕西师范大学学报, 28(2), 110-114。 
Guan, H. (1999). Calculation of the environmental capacity and tourist scale in Mount Wuyi. Fujian Architecture, 1, 2-4. 关辉(1999)。武夷山风景名胜区总体规划中 环境容量估算与旅游规模预测。福建建筑, 1, 2-4。

Guan, N. S., Yang, L., \& Wang, J. P. (1998). Forecasting tourism demand in Heqin. Social Scientist, supplementary issue, 68-70. 管宁生，杨丽，王建平(1998)。 鹤庆县旅游市场分析与预测。社会科学家, 增刊, 68-70。

Guo, L. H., \& Ou, F. (2007). Quantitative assessment on tourism receipts under shortterm economic fluctuations Guilin city. Journal of Leshan Teachers College, 22(5), 59-61. 郭丽华, 欧阳斐(2007)。桂林市旅游经济短期波动下的游客接待 量量化估测。乐山师范学院学报, 22(5), 59-61。

Guo, L., \& Jin, H. (2007). An empirical time series analysis of international tourist flows - A case study of Zhejiang Province. China Tourism Research, 3(1), 138-148.

Guo, X. F. (2007). A study on forecasting tourist arrivals in China based on the ARIMA model. Science Information, 8, 22-23. 过晓芳(2007)。基于ARIMA模型的国内 旅游人数预测研究。科技信息, $8,22-23$ 。

Guthrie, H. W. (1961). Demand for tourists' goods and services in a world market. Paper presented at the Regional Science Association.

Han, Y., \& Zhou, L. M. (2002). Forecasting the labor market of China tourism industry in the future 10 years. Quantitative Economy Technologies \& Economy Research, 3, 40-43. 韩颖, 周黎明(2002)。今后十年我国旅游业吸纳劳动力的数量预 测。数量经济技术经济研究, 3, 40-43。

Harding, H. (1993). The concept of 'Greater China': Themes, variations, and reservations. The China Quarterly, 136, 660-686.

Harvey, A. C. (1989). Forecasting Structural Time Series Models and the Kalman Filter. New York: John Wiley.

He, H., \& Ye, M. Q. (2006). Dynamic analysis on the relationship between China's tourism industry and the economy growth. Special Journal of Social Science, 2, 134-138. 和红, 叶民强(2006)。中国旅游业与经济增长相关关系的动态分析。 社会科学辑刊, 2, 134-138。

He, R. G., \& Deng, G. H. (2007). Using the time series model to predict tourist numbers in Guilin. Journal of Guangxi Academy of Sciences, 23(3), 153-156. 何荣国, 邓 国和(2007)。桂林市旅游人数的时间序列预测模型。广西科学院学报, 23(3), $153-156$ 。

Heung, V. C. S., \& Qu, H. (1998). Tourism shopping and its contributions to Hong Kong. Tourism Management, 19 (4), 383-386.

Hiemstra, S., \& Wong, K. K. F. (2002). Factors affecting demand for tourism in Hong Kong. Journal of Travel \& Tourism Marketing, 13(1/2), 43-62.

Hong Kong Economic and Trade Office, London (2005). Fruit of concerted efforts. Hong Kong Review, April 2005. [Accessed on 28 October 2008] URL: http://www.hketolondon.gov.hk/news/docs/Final_April05 issue.pdf. 
Huang, H. (2005). Analysis and forecasting of China's inbound tourism. Contemporary Manager, 18, 197-198. 黄河(2005)。中国入境旅游市场分析与预测。当代经 理人, $18,197-198$ 。

Huang, J. H., \& Min, J. C. H. (2002). Earthquake devastation and recovery in tourism: the Taiwan case. Tourism Management, 23(2), 145-154.

Huarng, K. H., Moutinho, L., \& Yu, T. H. K. (2006). An advanced approach to forecasting tourism demand in Taiwan. Journal of Travel \& Tourism Marketing, 21(4), 15-24.

Jia, R., \& Yu, J. G. (2004). Analysis of overseas tourist market structure in Dalian city. Journal of Hebei Normal University, 28(5), 524-527. 贾茹，俞金国(2004)。 大连市入境旅游市场分析。河北师范大学学报，28(5)，524-527。

Jiang, W. Y., Chen, C., \& Zhu, X. H. (2007). Analysis and forecasting of international tourism demand in Lantsang- Mekong Hypo region. World Regional Studies, 16(2), 66-72. 蒋文燕, 陈晨, 朱晓华(2007)。澜沧江一湄公河次区域国际旅游 发展态势及前景预测。世界地理研究，16(2), 66-72。

Kang, C. D., Zhuang, X. L., \& Wei, L. J. (2006). A grey theory-based model for forecasting market scale-A case study of the electronic tourism market in China. Journal of Shijiazhuang University of Economics, 29(2), 162-165. 康传德, 庄小 丽, 魏龙吉(2006)。基于灰色系统理论的市场潜力预测模型——我国旅游 电子商务市场为例。石家庄经济学院学报, 29(2), 162-165。

Kulendran, N., \& Shan, J. (2002). Forecasting China's monthly inbound travel demand. Journal of Travel \& Tourism Marketing, 13(1/2), 5-19.

Kuo, H. I., Chen, C. C., Tseng, W. C., Ju, L. F., \& Huang, B. W. (in press). Assessing impacts of SARS and Avian Flu on international tourism demand to Asia. Tourism Management.

Law, R. (1998). Room occupancy rate forecasting: A neural network approach. International Journal of Contemporary Hospitality Management, 10(6), 234-239.

Law, R. (2000). Back-propagation learning in improving the accuracy of neural networkbased tourism demand forecasting. Tourism Management, 21(4), 331-340.

Law, R. (2001). The impact of the Asian financial crisis on Japanese demand for travel to Hong Kong: A study of various forecasting techniques. Journal of Travel \& Tourism Marketing, 10(2/3), 47-65.

Law, R. (2004). Initially testing an improved extrapolative hotel room occupancy rate forecasting technique. Journal of Travel \& Tourism Marketing, 16(2/3), 71-77.

Law, R., \& Au, N. (1999). A neural network model to forecast Japanese demand for travel to Hong Kong. Tourism Management, 20(1), 89-97.

Law, R., \& Au, N. (2000). Relationship modelling in tourism shopping: A decision rules induction approach. Tourism Management, 21(3), 241-249.

Law, R., Goh, C., \& Pine, R. (2004). Modeling tourism demand: A decision rules based approach. Journal of Travel \& Tourism Marketing, 16(2/3), 61-69. 
Lee, C. C., \& Chien, M. S. (2008). Structural breaks, tourism development, and economic growth: Evidence from Taiwan. Mathematics and Computers in Simulation, 77(4), 358-368.

Lei, K. W., \& Chen, Y. (2007). Forecasting China's inbound tourists based on the BP neural network and ARIMA combined model. Tourism Tribune, 22(4), 20-25. 雷 可为, 陈瑛(2007)。基于BP神经网络和ARIMA组合模型的中国入境游客量预 测。旅游学刊, 22(4), 20-25。

Li, C. Y., \& Xie, F. (1993). Analysis and forecasting of tourism development in South Anhui Province. Forecasting, 3, 33-36. 李春英, 谢枫(1993)。皖南旅游经济发 展分析与预测。预测, 3, 33-36。

Li, F. H., Li, X. D., Yang, C. F., \& Lou, Z. F. (2007). A study of the international tourism market of Xinjiang Province. Resource Environment and Development, 1, 33-37. 李风华, 李晓冬, 杨彩风, 娄在风(2007)。新疆国际旅游客源市场研究。资 源环境与发展，1，33-37。

Li, G., Song, H., \& Witt, S. F. (2005). Recent developments in econometric modeling and forecasting. Journal of Travel Research, 44, 82-99.

Li, J. R. (2001). Forecasting the trends of China's inbound tourist markets. Journal of Shaanxi Economics \& Trade Institute, 14(1), 69-72. 李佼瑞(2001)。海外游客来 华旅游市场趋势预测。陕西经贸学院学报，14(1),69-72。

Li, J. Y. (2003). The dynamic trends and cycles of the development of tourism shopping in China. Economic Geography, 23(2), 272-274. 李景宜(2003)。我国旅游商品 业发展的动态趋势及波动周期。经济地理，23(2)，272-274。

Li, N. Y., \& Sun, G. N. (1998). Foundation and significance of the background-trend line of Xi'an city's inbound tourism. Journal of Northwest University, 28(4), 339343. 李乃英，孙根年(1998)。西安市境外旅游本底趋势线的建立及科学意 义。西北大学学报, 28(4), 339-343。

Li, Y. P. (2005). A study of China's domestic tourist expenditures based on an econometric model. Technoeconomics \& Management Research, 6, 54-55. 李云 鹏(2005)。基于计量经济学模型的国内城镇居民旅游消费研究。技术经济与 管理研究, 6, 54-55。

Li, Z. G., \& Su, Y. H. (2006). The application of the Familiarity with Scenic Destination in a gravity model. Journal of Guilin Institute of Tourism, 17(6), 665-667. 李志刚, 苏衍慧(2006)。亲景度指标在引力模型中的运用一一以美国旅桂(林)市场为 例。桂林旅游高等专科学校学报, 17(6), 665-667。

Lim, C. (1997a). An econometric classification and review of international tourism demand models. Tourism Economics, 3, 69-81.

Lim, C. (1997b). Review of international tourism demand models. Annals of Tourism Research, 24, 835-849.

Lim, C. (1999). A meta-analytic review of international tourism demand. Journal of Travel Research, 37, 273-284. 
Lim, C., \& Pan, G. W. (2005). Inbound tourism developments and patterns in China. Mathematics and Computers in Simulation, 68(5-6), 498-506.

Lin W. L., \& Lin, P. (2001). Emergence of the Greater China circle economies: Cooperation versus competition. Journal of Contemporary China, 10 (29), 695710.

Liu, H. B., \& Cui, L. (2004). Forecasting highways tourism earnings in the middle and west areas of Inner Mongolia. Highways \& Transportation in Inner Mongolia, 4, 37-39. 刘洪波, 崔琳(2004)。内蒙古中西部地区公路旅游收入预测。内蒙古公 路与运输, 4, 37-39。

Liu, M., Luo, H., \& Tao, C. F. (2006). Market segmentation based on the inbound tourism model in Jiangxi Province. Market Modernization, 464, 194-195. 刘敏, 罗华，陶春峰(2006)。江西省涉外游模型的建立以及市场划分。商场现代 化, 464,194-195。

Liu, S. (2003). Dynamic forecasts of tourist source markets. Journal of Qufu Normal University, 29(4), 107-110. 刘颂(2003)。旅游地客源市场动态预测方 法探讨。曲阜师范大学学报, 29(4), 107-110。

Liu, Y., Zhao, Y. X., Kong, F. A., \& Han, T. F. (2007). An application of the Logistic Growth Model to sustainable development of regional tourism - A case study of Mianshan Resort, Shanxi Province. Economic Geography, 27(4), 686-689. 刘勇, 赵艺学, 孔富安, 韩泰凡(2007)。Logistic模型在旅游业持续发展中的应用一 以山西省绵山风景区为案例。经济地理，27(4)，686-689。

Lu, F. (2005). A study on China's inbound tourism forecasting. Journal of Linyi Teachers' College, 27(6), 65-69. 鲁峰(2005)。中国入境旅游发展预测与开发对 策研究。临沂师范学院学报, 27(6), 65-69。

Lu, X. L. (2007a). A forecasting model for China tourism development based on production functions. Economic Research Guide, 1, 138-140. 陆相林(2007)。基 于生产函数的中国旅游发展总量预测模型研究。经济研究导刊, 1, 138140 。

Lu, X. L. (2007b). An application of the BP neural network method to the aggregate tourism forecasting. Journal of Beijing Institute of Education, 2(1), 8-11. 陆相林 (2007)。BP 神经网络在中国旅游发展总量预测中的应用。北京教育学院学 报, 2(1)，8-11。

Lu, X. Z., Hu, H. B., Wang, H. J., \& Deng, C. H. (2002). An analysis on tourism markets in Sand Lake scenic area of Ningxia Province. Journal of Nanjing Forestry University, 2(4), 61-63. 鲁小珍, 胡海波, 王汉杰, 邓存恒(2002)。宁夏沙湖风景 区的旅游市场分析。南京林业大学学报，2(4)，61-63。

Luo, J. M., \& Hou, W. N. (2000). Quantitative analysis of exchange earnings of the tourism industry in Hunan Province. Journal of Cent-South Industrial University, 6(4), 312-313. 罗金铭, 侯万能(2000)。湖南省旅游外汇收入增长的定量分析 与预测模型。中南工业大学学报，6(4),312-313。 
Luo, Z. X., \& Zhang, S. F. (2005). An application of sequence grey prediction to tourism statistics and forecasting-An example of Jiangsu Province. Journal of Nanjing University, 28(2), 117-121. 罗朝霞, 张树夫(2005)。数列灰预测在旅游统计与 预测上的应用一以江苏省为例。南京师大学报, 28(2), 117-121。

Ma, H. B. (2007). An analysis on the tourism receipts in tourist attractions during the May-Day golden week. Sci-Tech Information Development \& Economy, 17(5), 130-131. 马海波(2007)。旅游景区“五一”黄金周游客接待量分析。科技情报 开发与经济, 17(5), 130-131。

Mao, C. (2000). A comparison between several commonly used methods of tourism forecasting. Journal of Chongqing Normal University, 17, 87-90. 毛长义(2000)。 几种常用的旅游客源人数预测方法之比较。重庆师范学院学报, 17, 8790 。

Mei, H., Zhu, J. F., \& Wang, X. (2007). The characteristics and trends of air passengers' behaviours in China. Business Era, 13, 95-97. 梅虎, 朱金福, 汪侠(2007)。我国 航空旅客选择行为结构特征及趋势。商业时代, 13, 95-97。

Min, J. C. H. (2005). The effect of the SARS illness on tourism in Taiwan: An empirical study. International Journal of Management, 22(3), 497-506.

Nie, N. (2001). The significance of the trend line of China's inbound tourism. Journal of Changde Teachers University, 26(4), 48-49. 聂钠(2001)。中国国际入境旅游趋 势线的建立及意义。常德师范学院学报, 26(4), 48-49。

Ou, L., \& Zhang, Q. (2005). A grey model for China's tourist source market predictionAn example of Heibei Province. Journal of Yanshan University, 6, 98-100. 欧 蕾, 张琼(2005)。国内旅游客源市场的灰色预测模型——河北省为例。燕 山大学学报, 6, 98-100。

Ouyang, R. P., \& Hu, X. Q. (2007). A literature review of global and China's tourism demand studies. Journal of Nanjing University of Finance and Economics, 3, 8083. 欧阳润平, 胡晓琴(2007)。国内外旅游需求研究综述。南京财经大学学报, 3, 80-83。

Peng, M. W., Lub, Y., Shenkara, O., \& Wang, Y. L. (2001). Treasures in the China house: a review of management and organizational research on Greater China. Journal of Business Research, 52 (2), 95-110.

Peng, Z. Q., \& Qu, S. Q. (2003). Forecasting sightseeing visitor flows at Yunyang Forest Park using a grey model. Journal of Hunan Environment - Biological Polytechnic, 9(2), 157-160. 彭志奇, 屈术群(2003)。云阳森林公园游客规模灰色预测。湖 南环境生物职业技术学院学报, 9(2), 157-160。

Qin, J. H. (2005). Assessment on Guilin resort life cycle. Journal of Guilin Institute of Tourism, 16(4), 67-70. 覃江华(2005)。桂林旅游地生命周期的界定。桂林旅游 高等专科学校学报, 16(4),67-70。

Qin, L. G. (2000). Non-linear regression analysis and self-inertia forecasting of Guilin's inbound tourism. Journal of Guilin Institute of Technology, 20(2), 206-212. 秦立 
公(2000)。桂林入境旅游发展的非线性回归拟合与自惯性预测研究。桂林工 学院学报, 20(2), 206-212。

Qin, P. P., Lu, K. P., \& Ya, H. G. (2006). Research on forecasting models of tourism demand. Railway Transport and Economy, 28(8), 73-75. 覃频频, 陆凯平, 牙 韩高(2006)。旅游需求预测模型研究。铁道运输与经济, 28(8), 73-75。

Qu, H., \& Lam, S. (1997). A travel demand model for Mainland Chinese tourists to Hong Kong. Tourism Management, 18(8), 593-597.

Qu, H., Xu, P., \& Tan, A. (2002). A simultaneous equations model of the hotel room supply and demand in Hong Kong. International Journal of Hospitality Management, 2l(4), 455-462.

Ren, L. L., \& Liu, Z. M. (2006a). A comparative analysis on tourism demand forecasting methods. World Sci-Tech R\&D, 28(6), 84-88. 任来玲，刘朝明(2006)。旅游需 求预测方法的比较分析。世界科技研究与发展, 28(6),84-88。

Ren, L. L., \& Liu, Z. M. (2006b). A literature review on tourism demand forecasting methods. Tourism Tribune, 21(8), 90-92. 任来玲, 刘朝明(2006)。旅游需求预测 方法文献述评。旅游学刊, 21(8), 90-92。

Shan, J., \& Wilson, K. (2001). Causality between trade and tourism: Empirical evidence from China. Applied Economics Letters, 8(4), 279-283.

Shang, L., \& Qin, W. L. (2007). Analysis and forecasting of foreign exchange revenues of China's inbound tourism based on ARIMA and EGARCH models. Statistics Education, 4, 46-48. 尚林, 秦伟良(2007)。基于ARIMA和EGARCH模型的中 国入境旅游收汇预测分析。统计教育, 4, 46-48。

Sheldon, P. J. (1993). Forecasting tourism: Expenditure versus arrivals. Journal of Travel Research, 32, 13-20.

Shen, Z. J. (1999). An analysis on overseas tourist market in Henan Province. Area Research and Development, 18(2), 57-59. 沈振剑(1999)。河南省国际旅游客源 市场分析。地域研究与开发, 18(2),57-59。

Shen, Z. J. (2005). Forecasting the trend of tourism demand in Henan Province. Economic Survey, 4, 120-122. 沈振剑(2005)。河南省旅游流时空变化的预测及 发展趋势。经济经纬, 4,120-122。

Shi, C. K. (2005). An application of the grey theory to inbound tourism forecasting. Journal of Science of Teachers' College University, 25(3), 75-78. 史常凯 (2005)。灰色系统理论在旅游客源市场预测中的应用。高师理科学刊, 25(3), $75-78$ 。

Shi, J. J., Yang, Z. P., \& Zhang, H. Y. (2007). An assessment and forecasting on the competitiveness of inbound tourism in Xinjiang Province. Journal of Arid Land Resources and Environment, 21(8), 133-136. 石吉金, 杨兆萍, 张宏元(2007)。新 疆入境旅游竞争力评价及预测分析。王旱区资源与环境, 21(8)，133-136。

Shui, Q. S., \& Teng, Y. (2006). A study of tourism demand forecasting models-An example of Leshan Buddha scenic spot. Market Modernization, 458, 211-212. 税 
清双, 滕颖(2006)。景区游客流量预测模型研究一一乐山大佛景区为例。 商场现代化, 458, 211-212。

Sinclair, M. T., \& Stabler, M. (1997). The Economics of Tourism. London: Routledge.

Song, H., \& Fei, B. (2007). Modelling and forecasting international tourist arrivals to mainland China. China Tourism Research, 3(1), 20-40.

Song, H., \& Li, G. (2008). Tourism demand modelling and forecasting-A review of recent research, Tourism Management, 29, 203-220.

Song, H., \& Turner, L. (2006). Tourism demand forecasting. in L. Dwyer, \& P. Forsyth, (Eds.) International Handbook on the Economics of Tourism. Cheltenham: Edward Elgar.

Song, H., \& Witt, S. F. (2000). Tourism Demand Modelling and Forecasting: Modern Econometric Approaches. Oxford: Pergamon.

Song, H., \& Witt, S. F. (2006). Forecasting international tourist flows to Macau. Tourism Management, 27(2), 214-224.

Song, H., \& Wong, K. K. F. (2003). Tourism demand modelling: A time-varying parameter approach. Journal of Travel Research, 42(1), 57-64.

Song, H., Wong, K. K. F., \& Chon, K. K. S. (2003). Modelling and forecasting the demand for Hong Kong tourism. International Journal of Hospitality Management, 22(4), 435-451.

Su, J. J. (2006). Forecasting the inbound tourism market in Qinhai Province. Nationalities Research in Qinhai, 17(1), 118-121. 苏建军(2006)。青海省入境旅游市场的态 势分析及预测研究。青海民族研究，17(1), 118-121。

Sun, G. N. (1998). Foundation and significance of the background-trend line of international tourism in China. Geography Science, 18(5), 442-448. 孙根年 (1998)。我国境外旅游本底趋势线的建立及科学意义。地理科学，18(5), $442-448$ 。

Sun, G. N. (2000). Foundation of tourism background-trend line of 6 major source markets of China tourism. Systems Engineering Research \& Practices, 1, 140-143. 孙根年(2000)。我国6大境外客源市场旅游本底趋势线的建立。系统工程理 论与实践, $1,140-143$ 。

Sun, G. N. (2001). The dynamic trends and cycles of inbound tourism in Xi'an city. Journal of Northwest University, 31(6), 514-517. 孙根年(2001)。西安市境外旅 游业发展的动态趋势及波动周期。西北大学学报，31(6), 514-517。

Sun, G. N., \& Ma, L. J. (2007). A correlation analysis of tourist arrivals and the comfortable degree of climate in Xi'an city. Tourism Tribune, 22(7), 34-39. 孙 根年,马丽君(2007)。西安旅游气候舒适度与客流量年内变化相关性分析。旅 游学刊, 22(7), 34-39。

Sun, T. Y., \& Hou, R. M. (2004). A quantitative analysis and forecasts of the tourism labor forces over China's 11 th Five-Year Economic Development Plan. Economic Survey, 1，139-141. 孙天厌，侯仁民(2004)。“十一五”我国旅游业吸纳劳动力 的数量分析与预测。经济经纬, 1, 139-141。 
Sun, Y. P., Zhang, L., \& Lv, R. Y. (2002). Forecasting tourist arrivals using the neural network method. Human Geography, 17(6), 50-52. 孙燕平, 张琳, 吕仁义 (2002)。旅游客源预测的神经网络方法。人文地理, 17(6), 50-52。

Sun, Y. Z., Ma, Y. F., Sun, G. N., \& Wu, B. (1998). Analysis and forecasting of Kunming's major Asian tourist markets. Journal of Shaanxi Normal University, 26(1), 95-97. 孙玉贞，马耀峰，孙根年，吴冰(1998)。昆明市亚太地区主要 旅游客源及特征分析与预测。陕西师范大学学报，26(1),95-97。

Tang, W. B., Zhou, B. G., \& Zhang, Y. G. (2007). An approach to forecasting the domestic tourism demand. Journal of Anhui Normal University, 30(4), 508-511. 唐文兵, 周秉根, 张圆刚(2007)。预测城镇居民境内旅游人数的一种方法。安 徽师范大学学报, 30(4), 508-511。

Tang, W. B., Zhou, B. G., Zhang, Y. G., \& Zhang, X. F. (2007). An application of MirWinters Exponential Smoothing to forecasting tourists quantity. Country Resources Technology Management, 24(4), 79-84. 唐文兵, 周秉根, 张圆刚, 张贤 付(2007)。缪尔-温特斯指数平滑法在旅游人数预测中的应用研究。国土资源 科技管理，24(4), 79-84。

Tang, X. Y., Zhao, L. M., \& Qin, B. (2007). The grey theory and its application to tourism forecasting-An example of Guilin. Journal of Xidian University, 17(2), 15. 唐晓云, 赵黎明, 秦 涁(2007)。灰色系统理论及其在旅游预测中的应 用——以广西桂林为例。西安电子科技大学学报, 17(2), 1-5。

Teng, X., \& Li, S. M. (2006). Forecasting tourism demand in Xi' an city using the neural network method. Journal of Xidian University, 16(5), 21-24. 滕昕, 李树民 (2006)。西安市旅游客源预测的人工神经网络方法分析。西安电子科技大学 学报, 16(5), 21-24。

Tian, X. Z. (2001). Analysis of the US tourism demand for Chongqing city. Journal of Chongqing Institute of Commerce, 3, 18-20. 田喜洲(2001)。重庆市美国客源市 场分析、预测与开发对策。重庆商学院学报， 3, 18-20。

Toshinori, M. (1998). Fundamentals of the New Artificial Intelligence. New York: Springer.

Tsai, P. L., \& Wang, K. L. (1998). Competitiveness of international tourism in Taiwan: US versus Japanese visitors. Applied Economics, 30(5), 631-641.

Tse, R. Y. C. (2001). Estimating the impact of economic factors on tourism: Evidence from Hong Kong. Tourism Economics, 7(3), 277-293.

Uysal, M., \& Crompton, J. L. (1985). An overview of approaches used to forecast tourism demand. Journal of Travel Research, 24, 7-15.

Vanhove, N. (1980). Forecasting in Tourism. The Tourist Review, 3, 2-7.

Wang, C. H. (2004). Predicting tourism demand using fuzzy time series and hybrid grey theory. Tourism Management, 25(3), 367-374.

Wang, C. H., \& Hsu, L. C. (2008). Constructing and applying an improved fuzzy time series model: Taking the tourism industry for example. Expert Systems With Applications, 34(4), 2732-2738. 
Wang, C. H., Sun, G. N., \& Ma, Y. F. (2004). Analysis of the cycles of Chinese inbound tourism. Journal of Ningxia University, 25(2), 174-179. 王彩红, 孙根年, 马耀峰 (2004)。20年来中国入境旅游业的波动周期及影响因素。宁夏大学学报, $\underline{25(2)}, 174-179$ 。

Wang, D. L. (2004). An application of grey forecasting in predicting the tourist number and tourism revenue during the October $1^{\text {st }}$ golden week. Journal of Taishan University, 26(6), 6-9. 王道林(2004)。灰色理论在黄金周旅游人数及旅游收入 预测中的应用。泰山学院学报, 26(6), 6-9。

Wang, H. H. (2001). Forecasting China's inbound tourism using a grey model. Journal of Tianshui Administration Institute, 3, 10-13. 王海鸿(2001)。中国入境旅游的灰 色预测。天水行政学院学报, 3, 10-13。

Wang, H., Zhang, E. X., \& Wang, T. (1997). Dynamic forecasts of international tourists to Beijing. Statistics \& Information Tribune, 2, 26-32. 王洁, 张恩祥, 王涛 (1997)。境外游客流到北京的动态预测。统计与信息论坛, 2, 26-32。

Wang, J. Q. (2003). A statistical analysis and forecasts of tourist arrivals. Journal of Huangshan University, 5(1), 95-99. 汪季清(2003)。旅游者人数变动的统计预 测分析。黄山学院学报, 5(1),95-99。

Wang, J. Y., \& Hua, C. C. (2006). Modelling tourist flows in Yunnan Province during the golden week of the Spring Festival. Journal of Yunnan University, 28(S1), 15-18. 王景艳, 化存才(2006)。春节黄金周云南旅游片区人流量的模型分析。云南 大学学报, 28(S1), 15-18。

Wang, L. T. (2000). Research on overseas tourism market in Zibo city. Journal of Taian Teachers College, 22(5), 11-16. 王雷亭(2000)。淄博市海外旅游市场研究。泰 安师专学报, 22(5), 11-16。

Wang, M. L. (2002). Forecasting the tourist market in Fuling. Journal of Leshan Teachers College, 17(3), 96-100. 汪明林(2002)。涪陵旅游客源市场分析、预 测与定位。乐山师范学院学报, 17(3),96-100。

Wang, X. (2006). Analysis and forecasting on tourism industry structure-A case study of Hubei Province. Market Modernization, 454, 267-268. 王晞(2006)。旅游产业的 结构分析、区位优势与发展预测——湖北省神农架林区案例。商场现代化, $\underline{454}, 267-268$ 。

Wei, H. Y. (1999). A grey model for forecasting overseas tourism demand for Shenzhen city. Journal of Northwest University, 29(4), 361-363. 卫海燕(1999)。深圳市境 外游客市场的灰色预测模型。西北大学学报，29(4),361-363。

Wei, H. Y. (2000). Forecasting four major overseas tourist markets of Shanghai using a grey model. Journal of Shaanxi Normal University, 28(1), 106-109. 卫海燕 (2000)。上海市四个主要境外旅游客源市场的灰色预测模型。陕西师范大学 学报, 28(1), 106-109。

Wei, M., Yuan, X. J., \& Liu, Z. B. (2005). An analysis on the change of the overseas tourist market structure. World Regional Studies, 14(2), 92-95. 魏敏, 袁秀杰, 
刘治波(2005)。山东省境外旅游客源市场结构变化分析。世界地理研究, $14(2)$, 92-95。

Wei, Q. E., \& Liu, X. P. (1997). A dynamic forecasting model for Xi'an inbound tourism. Journal of Shaanxi Normal University, 25(2), 67-71. 魏启恩，刘新平(1997)。 西安市境外游客动态预测模型。陕西师范大学学报, 25(2), 67-71。

Wei, X., \& Yu, L. Y. (2005). An application of the quantitative method on economic fluctuations in tourism destinations. Statistics and Decision, 13-14. 魏翔, 于凌云 (2005)。对旅游目的地短期经济波动进行量化测定的计量方法。统计与决 策, 13-14。

Witt, S. F., \& Turner, L. W. (2002). Trends and forecasts for inbound tourism to China. Journal of Travel \& Tourism Marketing, 13(1/2), 99-109.

Witt, S. F., \& Witt, C. A. (1995). Forecasting tourism demand: A review of empirical research. International Journal of Forecasting, 11, 447-475.

Wong, K. K. F. (1997). The relevance of business cycles in forecasting international tourist arrivals. Tourism Management, 18(8), 581-586.

Wong, K. K. F., Song, H., \& Chon, K. S. (2006). Bayesian models for tourism demand forecasting. Tourism Management, 27(5), 773-780.

Wong, K. K. F., Song, H., Witt, S. F., \& Wu, D. C. (2007). Tourism forecasting: To combine or not to combine? Tourism Management, 28(4), 1068-1078.

World Tourism Organization (UNWTO) (2000). Tourism 2020 Vision. Madrid, Spain: UNWTO.

World Tourism Organization (UNWTO) (2008). UNWTO World Tourism Barometer, 6(1). Madrid, Spain: UNWTO.

Wu, J. H., Ge, Z. S., \& Yang, D. Y. (2002). An artificial neural network method for international tourism demand forecasting-Taking the Japanese demand for Hong Kong as an example. Tourism Tribune, 17(3), 55-59. 吴江华, 葛兆帅, 杨达源 (2002)。基于人工神经网络的国际入境旅游需求的定量分析与预测一以日 本对香港的国际旅游需求分析为例。旅游学刊, 17(3), 55-59。

Wu, J., \& Liu, X. P. (2001). A time series model for forecasting tourism foreign exchange earnings in China. Basic Sciences Journal of Textile Universities, 14(1), 51-55. 武娇, 刘新平(2001)。我国国际旅游外汇收入的时间序列预测模型。纺 织高校基础科学学报, 14(1), 51-55。

Xie, B. L., \& Wu, G. N. (1998). An application of the time sequence method to tourism management. Journal of Guilin Institute of Tourism, 9(2), 9-14. 谢北立，吴光年 (1998)。旅游管理中的时序分析方法。桂林旅专学报，9(2)，9-14。

Xie, N. (2007). Forecasting the tourism life cycle using a time series model. Assembly of Science and Education, 188. 解妮(2007)。时间序列调和模型对旅游周期的预 测。科教文汇, 188。

$\mathrm{Xu}, \mathrm{C} . \mathrm{T}$. (2003). The current situation of China's domestic tourism and its development trend. Journal of Shandong Normal University, 18(2), 62-65. 徐春堂(2003)。中 国国内旅游的发展现状与前景预测。山东师范大学学报，18(2)，62-65。 
$\mathrm{Xu}, \mathrm{H}$. (2000). Analysis and forecasting of Sichuan's tourism economy. Economic Geography, 20(6), 121-124. 许虹(2000)。四川省旅游经济分析与预测。经济 地理, 20(6), 121-124。

$\mathrm{Xu}, \mathrm{M} .$, \& $\mathrm{Yu}, \mathrm{H}$. (1997). A forecasting model for macroeconomic development of the tourism industry in Jilin Province. Journal of Jilin Forestry University, 13(2), 7679. 徐明, 于辉(1997)。吉林省旅游业宏观经济发展的预测模型。吉林林学院 学报, 13(2), 76-79。

Xu, S., \& Huang, Y. L. (2005). An application of the grey theory to the development of the tourism industry in Foshan city. Enterprise Economy, 297(5), 101-102. 徐 颂，黄耀丽(2005)。灰色系统理论在佛山市旅游业发展分析中的应用。企业 经济, 297(5), 101-102。

Yan, F., \& Meng, J. J. (2005). An application of the Logistic Growth Model to tourism forecasting-A case study of Suiyang, Guizhou Province. Human Geography, 4, 87-91. 严汾, 蒙吉军(2005)。Logistic增长模型在游客流量预测中的应用

以贵州省绥阳县为例。人文地理, 4, 87-91。

Yang, J. Q. (2001). A forecasting model of international visitor arrivals to China. Basic Sciences Journal of Textile Universities, 14(4), 363-364. 杨军强(2001)。国际来 华旅游人数动态预测。纺织高校基础科学学报, 14(4), 363-364。

Yang, Y., Zhang, X. Y., \& Zhang, J. Q. (2003). Tourism forecasting and statistical analysis. Journal of Southwest Agricultural University, 1(2), 62-65. 杨宇，张孝 友, 张集琼(2003)。旅游统计预测分析。西南农业大学学报，1(2),62-65。

Ye, G. X. (2003). Statistical forecasting of the trend of China's inbound tourism development. Journal of Jiujiang Vocational \& Technical College, 4, 49-50. 叶桂 香(2003)。中国入境旅游业发展态势的统计预测。九江职业技术学院学报, 4, 49-50。

Yin, Y., Hu, G. H., \& Qiu, Y. Q. (2004). Forecasting and analysis of tourism demand in Yunnan based on the statistical learning theory. Journal of Yunnan University, 26, 23-26. 殷英, 胡光华, 邱宇青(2004)。基于统计学习理论的云南旅游需求预测 与分析。云南大学学报, 26, 23-26。

Yu, C. Y. (2006). A study on the consumption structure of overseas tourists in Jilin Province based on the statistical forecasting theory. Journal of Changchun University, 16(4), 20-22. 于春艳(2006)。应用统计预测理论研究吉林省海外游 客消费结构。长春大学学报, 16(4), 20-22。

Yu, J. G., \& Wang, L. H. (2005). Evaluation on the recovery of China's inbound tourism in the late SARS period based on the ARIMA model. Statistics \& Decision, 07X, 84-86. 俞金国，王丽华(2005)。后SARS时期中国入境旅游人数恢复评估 基于ARIMA模型。统计与决策, 07X, 84-86。

Zhang, E. X. (2000). Dynamic forecasting methods for inbound tourist arrivals in China. Mathematics in Practice and Theory, 30(1), 122-127. 张恩祥(2000)。来华境外 游客的动态预测方法。数学的实践与认识, 30(1),122-127。 
Zhang, H. C. (2007). An application of time series models for China's international tourism revenue forecasting. Economic Review, 2, 140-145. 张华初(2007)。中国 国际旅游收入的时间序列模型。经济评论，2，140-145。

Zhang, H. M. (1995). Grey forecasting for forest tourism flows. Sichuan Forest Exploration Design, 4, 29-33. 张洪明(1995)。森林旅游客流量引入残差信息的 灰色预测。四川林勘设计, 4,29-33。

Zhang, H. M., \& Lu, L. (2004). The cycles of inbound tourism growth in China. Journal of Anhui Normal University, 27(4), 457-460. 张宏梅, 陆林(2004)。中国入境 旅游者增长的周期性波动。安徽师范大学学报, 27(4), 457-460。

Zhang, H. X., \& Ma, Y. F. (2005). Regression analysis of China's inbound tourism markets. Resource Development \& Market, 21(2), 105-106. 张红贤，马耀峰 (2005)。中国入境旅游市场的多元回归预测。资源开发与市场，21(2)，105106 。

Zhang, J. Q., Kang, X. L., \& Li, F. (2007). Analysis and forecasting of key indicators of China's tourism development. Journal of Northwest A\&F University, 7(2), 68-71. 张景群, 康秀亮, 李菲(2007)。中国旅游业发展若干指标分析与预测。西北农 林科技大学学报, 7(2), 68-71。

Zhang, L. C. (2004). Analysis and forecasting of China's domestic tourism market scale. Area Research and Development, 23(1), 59-61. 张立生(2004)。我国国内旅游市 场规模分析与预测。地域研究与开发, 23(1), 59-61。

Zhang, L., \& Chen, J. C. (2007). An application of an intervention model for tourism demand forecasting. Jiangsu Business Tribune, 5, 81-83. 张玲, 陈军才(2007)。 干预模型在旅游需求预测中的运用。江苏商论， 5, 81-83。

Zhang, L., \& Li, X. Y. (2007). Forecasting tourist flows based on a grey model-An example of Heibei Province. Market Modernization, 506, 233-234. 张龙, 李翔宇 (2007)。基于灰色模型的旅游流量预测方法探讨一以河北省为例。商场现 代化, 506, 233-234。

Zhang, Q. M., \& Wang, W. S. (2002). Forecasting Tourism demand in Ningxia Province. Journal of Xinyang Teachers College, 15(2), 162-165. 张启敏, 汪文帅(2002)。 宁夏旅游需求量的预测。信阳师范学院学报，15(2)，162-165。

Zhang, X. L., \& Wang, P. X. (2005). Analysis of inbound tourism market characteristics and trends in Shanxi Province since 1990. Statistics and Management, 25(5), 2734. 张心灵, 王平心(2005)。1990年以来陕西省入境旅游市场特征及其趋势分 析。数理统计与管理, 25(5), 27-34。

Zhang, X. M. (2003). A factor analysis of China's tourism revenue forecasting. Railway Construction Technology, 6, 67-68. 张学梅(2003)。我国旅游总收入预测因子 研究。铁道建筑技术, 6, 67-68。

Zhang, Y. L., Zhou, A. M., \& Wang, X. X. (2000). Tourism forecasting models and applications. Journal of the Hebei Academy of Sciences, 1(2), 62-65. 张友兰, 周 爱民, 王新学(2000)。旅游预测模型及应用。河北省科学院学报, 17(2),6265 。 
Zhao, C. R. (2004). Environment capacity estimation and tourism scale forecasting of scenic spots. Journal of Southeast University of Science and Technology, 19(2), 72-75. 赵春容(2004)。风景名胜区环境容量估算与旅游规模预测。西南科技 大学学报, 19(2), 72-75。

Zhao, L. M., Wu, W. Q., \& Liu, J. K. (2006). A study on forecasting tourist flows using the neural network method based on wavelet analysis. Journal of Systems Engineering, 21(2), 221-224. 赵黎明, 吴文清, 刘嘉焜(2006)。基于小波分析的 游客流量神经网络预测研究。系统工程学报, 21(2), 221-224。

Zhao, W. Q., \& Jia, H. M. (2005). An analysis on the development of the tourism industry in Anhui Province. Business Era·Theory, 23, 92-93. 赵文清, 贾慧敏 (2005)。安徽旅游业发展分析及对策。商业时代·理论，23，92-93。

Zhao, Z., \& Yin, H. T. (2004). Forecasting tourist arrivals in new destinations. Human Geography, 19(6), 58-61. 赵哲, 尹怀庭(2004)。试论新开发旅游区的游客量预 测分析。人文地理, 19(6), 58-61。

Zheng, J. H., \& Liu, P. (2001). Linear combination forecasts of international tourist arrivals in Xinjiang Province. Journal of Communication \& Transportation Systems Engineering and Information, 1(2), 140-143. 郑江华，刘平(2001)。新 疆国际旅游客源量的线性组合预测。交通运输系统工程与信息，1(2)，140143。

Zheng, Y., \& Zhu, C. Y. (2006). Regression forecasting models for domestic tourism in Dazhou city. Resource Development \& Market, 22(5), 422-424. 郑颖, 朱创业 (2006)。达州市国内旅游市场回归预测模型研究。资源开发与市场, 22(5), 422-424。

Zhou, J. S., \& Liu, X. P. (1996). Forecasting inbound tourist markets of Kunming. Journal of Shaanxi Normal University, 24(4), 75-78. 周建设，刘新平(1996)。 昆明境外游客市场预测探讨。陕西师范大学学报，24(4),75-78。

Zhou, P., \& Ren, J. L. (2004). Analysis and forecasting of China's inbound tourist markets. Area Research and Development, 23(5), 68-72. 周鹏, 任建兰(2004)。中 国入境旅游客源市场格局及发展预测。地域研究与开发, 23(5), 68-72。

Zhu, C. J., Tang, D. S., \& Ma, W. B. (2006). Forecasting tourist numbers for agricultural tourism based on they grey theory and BP neural network. Journal of Anhui Agri. Sci., 34(4), 612-614. 朱春江, 唐德善, 马文斌(2006)。基于灰色理论和BP神经 网络预测观光农业旅游人数的研究。安徽农业科学, 34(4), 612-614。

Zhu, L. F., \& Pan, X. (2005). Tourist source market forecasting based on a grey model-A case study of Nanwan scenic spot in Xinyang. Journal of Xinyang Normal University, 18(3), 293-296. 朱良峰, 潘信(2005)。基于灰色模型的旅游地客源 预测——以信阳南湾风景区为例。信阳师范学院学报，18(3)，293-296。

Zhu, X. H., Yang, X. C., \& Cai, Y. L. (2005). Forecasting tourist source markets based on a grey model-A case study of China's inbound tourism. Economic Geography, 25(2)，232-235. 朱晓华, 杨秀春, 蔡运龙(2005)。基于灰色系统理论的旅游客 源预测模型——中国入境旅游客源为例。经济地理，25(2)，232-235。 
Table 1 Summary of Tourism Demand Modelling and Forecasting Studies on Greater China Published in International Journals (1992-2008)

\section{Legend}

1. Data frequency

A: annual

CS: cross sectional

$\mathrm{D}$ : daily

M: monthly

Q: quarterly

SA: semi-annual

W: weekly

2. Region focused

D: domestic tourism

I: as a destination

$\mathrm{O}$ : as an country/region of origin

\section{Dependent variable}

EX: exports

HOR: hotel occupancy rate

IM: imports

TA: tourist arrivals

TE: tourism receipts/expenditure

4. Independent variable

BC: business cycle

$\mathrm{C}$ : relative tourism price unadjusted by ER

$\mathrm{C}_{\mathrm{d}}$ : tourism price in destination

$\mathrm{C}_{\mathrm{o}}$ : tourism price in origin country/region

D: dummy variable

Dis: travel distance

DT: deterministic (linear) trend

ER: exchange rate

HR: average hotel rate

LS: length of stay

$\mathrm{ME}$ : marketing expenditure

NAC: No. of tourist accommodations

OEI: other economic indicator

P: population

$\mathrm{RC}$ : ER-adjusted relative price

$\mathrm{RPI}$ : retail price index

SC: substitute price

SF: TC to substitute destinations

TC: travel cost (airfare)

TS: travel cost by surface

TT: travel time

TV: trade volume

$\mathrm{Y}$ : income in origin country

$\mathrm{Y}_{\mathrm{d}}$ : income in destination country

\begin{tabular}{ll}
\hline Study & $\begin{array}{l}\text { Data Frequency } \\
\text { and Sample (1) }\end{array}$
\end{tabular}

\section{Modelling and Forecasting Methods}

ADLM: autoregressive distributed lag model

AR: autoregressive process

$\operatorname{AR}(\mathrm{I}) \mathrm{MA}(\mathrm{X})$ autoregressive (integrated) moving average

(cause effect) model

-In: with intervention

BSM: non-causal basic structural model

CI: cointegration

ECM: error correction model

ES: exponential smoothing

FTS: fuzzy time series

GA: genetic algorithm

GARCH: generalised autoregressive conditional

heteroscadesticity model

GM: grey model

GraM: gravity model

HM: non-linear Hammerstein model

MA: moving average

MC: Markoff chain

Naïve1: no-change model

Naïve2: constant growth rate model

NN: neural network

PDR: panel data regression

RS: rough sets modelling

SA: spectral analysis

SARIMA: seasonal ARIMA

SES: simultaneous equation system

SR: static regression

STSM: structural time series model

SVR: support vector regression

TEM: trend extrapolation model

TVP: time varying parameter model

VAR: vector autoregression

-B: Bayesian

-U: unrestricted

Note: a method in bold type refers to the best-performing one in forecasting competition

6. Forecasting exercise

$\mathrm{CF}$ : combination of forecasts

FC: forecasting competition

Ex ante: forecasting future demand

Ex post: evaluating out-of-sample forecast accuracy (with no competition)

\begin{tabular}{|c|c|c|c|c|c|c|}
\hline & & & & & Methods (5) & \\
\hline $\begin{array}{l}\text { Athiyaman \& } \\
\text { Bobertson (1992) }\end{array}$ & M: 86.01-89.12 & $\begin{array}{l}\text { Hong Kong from } \\
\text { Thailand }\end{array}$ & TA & & Naïvel MA ES & $\mathrm{FC}$ \\
\hline Au \& Law (2000) & A: $83-96$ & Hong Kong (I) & $\begin{array}{l}\text { TE- } \\
\text { sightseeing }\end{array}$ & LS OEIs & $\mathrm{RS}$ & Ex post \\
\hline Au \& Law (2002) & A: $83-96$ & Hong Kong (I) & TE- dinning & LS OEIs & $\mathrm{RS}$ & Ex post \\
\hline Cai et al (2002) & CS: 97 & Mainland China & TE & $\mathrm{Y} / \mathrm{P} \mathrm{D}$ & SR & Ex ante \\
\hline
\end{tabular}

(D) 


\begin{tabular}{|c|c|c|c|c|c|c|}
\hline $\begin{array}{l}\text { Cai \& Knutson } \\
\text { (1998) }\end{array}$ & A: $84-95$ & $\begin{array}{l}\text { Mainland China } \\
\text { (D) }\end{array}$ & TA & Y OEI D & SR & Ex ante \\
\hline $\begin{array}{l}\text { Chen \& Wang } \\
\text { (2007) }\end{array}$ & Q: 85.1-01.4 & Mainland China (I) & TA & & $\begin{array}{l}\text { GA-SVR NN } \\
\text { SARIMA }\end{array}$ & $\mathrm{FC}$ \\
\hline $\begin{array}{l}\text { Cheung \& Law } \\
\text { (2001) }\end{array}$ & A: $83-97$ & Hong Kong (I) & TE-hotels & HR C TA D & $\mathrm{SR}$ & \\
\hline Cho (2001) & Q: 75.1-97.4 & Hong Kong (I) & TA & $\mathrm{C}_{\mathrm{o}}$ IM EX OEIs & $\begin{array}{l}\text { ARIMAX } \\
\text { ARIMA ES }\end{array}$ & $\mathrm{FC}$ \\
\hline Cho (2003) & M: 74.01-00.12 & Hong Kong (I) & TA & & NN ES ARIMA & $\mathrm{FC}$ \\
\hline $\begin{array}{l}\text { Goh \& Law } \\
(2002)\end{array}$ & M: 80.01-00.08 & Hong Kong (I) & TA & & $\begin{array}{l}\text { SARIMA-In } \\
\text { SARIMA Naïve1,2 } \\
\text { MA ES ARIMA }\end{array}$ & $\mathrm{FC}$ \\
\hline $\begin{array}{l}\text { Goh \& Law } \\
(2003)\end{array}$ & A: $85-00$ & Hong Kong (I) & TA & Y C P TV ER & $\mathrm{RS}$ & Ex post \\
\hline Goh et al. (2008b) & A: $87-02$ & $\begin{array}{l}\text { Hong Kong from } \\
\text { UK US }\end{array}$ & TA & $\begin{array}{l}\text { Y RC SC TV P } \\
\text { D OEIs }\end{array}$ & $\mathrm{RS}$ & Ex post \\
\hline Guo \& Jin (2007) & M: 82.07-03.06 & $\begin{array}{l}\text { Zhejiang Province } \\
\text { (I) }\end{array}$ & TA & & MA & \\
\hline $\begin{array}{l}\text { Hiemstra \&Wong } \\
(2002)\end{array}$ & M: 90.01-98.12 & Hong Kong (I) & $\mathrm{TA} / \mathrm{P}$ & $\begin{array}{l}\text { Y/P C SC ER } \\
\text { TC SF D OEIs }\end{array}$ & ADLM & \\
\hline $\begin{array}{l}\text { Huang \& Min } \\
(2002)\end{array}$ & M: 79.01-00.07 & Taiwan (I) & TA & & SARIMA & Ex post \\
\hline $\begin{array}{l}\text { Huang et al. } \\
\text { (2006) }\end{array}$ & M: 84.01-05.09 & Taiwan (I) & TA & & $\begin{array}{l}\text { NN-FTS FTS } \\
\text { ARIMA }\end{array}$ & $\mathrm{FC}$ \\
\hline $\begin{array}{l}\text { Kulendran \& Shan } \\
(2002)\end{array}$ & M: 88.01-01.12 & Mainland China (I) & TA & & $\begin{array}{l}\text { SARIMA } \\
\text { ARIMA AR BSM } \\
\text { Naïve1 }\end{array}$ & $\begin{array}{l}\mathrm{FC} \\
\text { Ex ante }\end{array}$ \\
\hline Kuo et al. (2008) & M: 01.01-06.09 & $\begin{array}{l}\text { Mainland China } \\
\text { Hong Kong Taiwan } \\
\text { (I) }\end{array}$ & TA & D OEIs & ARMAX PDR & \\
\hline Law (1998) & A: $73-95$ & Hong Kong hotels & HOR & TA LS OEIs & NN SR Naïve1 & $\mathrm{FC}$ \\
\hline Law (2000) & A: $66-96$ & $\begin{array}{l}\text { Taiwan to Hong } \\
\text { Kong }\end{array}$ & TA & $\begin{array}{l}\text { Y RC ER P ME } \\
\text { HR }\end{array}$ & $\begin{array}{l}\text { Naïve1 ES MA } \\
\text { SR NN }\end{array}$ & $\mathrm{FC}$ \\
\hline Law (2001) & A: $67-98$ & $\begin{array}{l}\text { Hong Kong from } \\
\text { Japan }\end{array}$ & TA & Y HR ER P ME & $\begin{array}{l}\text { Naïve1,2 MA ES } \\
\text { SR NN }\end{array}$ & $\mathrm{FC}$ \\
\hline Law (2004) & A: $67-98$ & Hong Kong hotels & HOR & & $\begin{array}{l}\text { TEM ES MA } \\
\text { Naïve1,2 }\end{array}$ & $\mathrm{FC}$ \\
\hline Law \& Au (1999) & A: $77-97$ & $\begin{array}{l}\text { Hong Kong from } \\
\text { Japan }\end{array}$ & TA & $\begin{array}{l}\text { RC P ER ME } \\
\text { HR }\end{array}$ & $\begin{array}{l}\text { SR Naïve1 ES } \\
\text { MA NN }\end{array}$ & \\
\hline Law \& Au (2000) & A: $83-96$ & Hong Kong (I) & TE-shopping & LS OEIs & $\mathrm{RS}$ & Ex post \\
\hline Law et al (2004) & A: $76-96$ & $\begin{array}{l}\text { Hong Kong from } \\
\text { Japan }\end{array}$ & TA & $\begin{array}{l}\text { HR C ER P Y/P } \\
\text { ME }\end{array}$ & $\mathrm{RS}$ & Ex post \\
\hline $\begin{array}{l}\text { Lee \& Chien } \\
(2008)\end{array}$ & A: $59-03$ & Taiwan (I) & TA TE & Y ER & $\mathrm{CI}$ & \\
\hline Lim \& Pan (2005) & Q: 86.1-00.4 & $\begin{array}{l}\text { Mainland China } \\
\text { from Japan }\end{array}$ & TA & & $\begin{array}{l}\text { AR MA ARMA } \\
\text { SARMA }\end{array}$ & \\
\hline Min (2005) & M: 79.01-03.11 & Taiwan (I) & TA & & SARIMA & Ex post \\
\hline Qu \& Lam (1997) & A: $84-95$ & $\begin{array}{l}\text { Mainland China to } \\
\text { Hong Kong }\end{array}$ & TA & Y/P C ER D & SR & \\
\hline Qu et al (2002) & A: $80-98$ & Hong Kong hotels & HOR & $\begin{array}{l}\text { HR ER TA Y } \\
C_{d} \text { D OEIs }\end{array}$ & SES & \\
\hline $\begin{array}{l}\text { Shan \& Wilson } \\
\text { (2001) }\end{array}$ & M: 87.01-98.01 & Mainland China (I) & $\begin{array}{l}\text { TA Y RC } \\
\text { IM+EX ER }\end{array}$ & $\begin{array}{l}\text { TA Y RC } \\
\text { IM+EX ER }\end{array}$ & VAR & \\
\hline Song \& Fei (2007) & A: $85-05$ & Mainland China (I) & $\mathrm{TA}$ & Y RC SC D & ADLM & Ex ante \\
\hline $\begin{array}{l}\text { Song \& Witt } \\
(2006)\end{array}$ & Q: 92.1-03.2 & Macau (I) & TA & Y RC SC & VAR & Ex ante \\
\hline
\end{tabular}




\begin{tabular}{|c|c|c|c|c|c|c|}
\hline $\begin{array}{l}\text { Song \& Wong } \\
(2003)\end{array}$ & A: $73-00$ & Hong Kong (I) & TA & Y RC SC & TVP & \\
\hline Song et al (2003) & A: $73(81)-00$ & Hong Kong (I) & TA & Y RC SC D & ADLM & $\mathrm{FC}$ \\
\hline $\begin{array}{l}\text { Tsai \& Wang } \\
\text { (1998) }\end{array}$ & A: 73-94 & $\begin{array}{l}\text { Taiwan from US, } \\
\text { Japan }\end{array}$ & TA & C ER DT D & SR & \\
\hline Tse (2001) & A: $73-98$ & Hong Kong (I) & $\begin{array}{l}\text { TA TE/P } \\
\text { HOR }\end{array}$ & Y TA ER LS & ADLM & \\
\hline Wang (2004) & A: $89-01$ & Taiwan (I) & $\mathrm{TA}$ & DT & $\begin{array}{l}\text { FTS GM Markov- } \\
\text { GM }\end{array}$ & $\mathrm{FC}$ \\
\hline $\begin{array}{l}\text { Wang \& Hsu } \\
\text { (2008) }\end{array}$ & A: $90-02$ & Taiwan to US & TA & & FTSes & $\mathrm{FC}$ \\
\hline $\begin{array}{l}\text { Witt \& Turner } \\
(2002)\end{array}$ & A: $82-99$ & Mainland China (I) & TA & Y RC TC & STSM & Ex ante \\
\hline Wong (1997) & Q: 75.1-95.4 & Hong Kong (I) & TA & DT BC & $\begin{array}{l}\text { TEMs Naïve1,2 } \\
\text { ARIMA }\end{array}$ & $\mathrm{FC}$ \\
\hline Wong et al (2006) & A: $73-00$ & Hong Kong (I) & TA & Y RC SC D & VAR-B VAR-U & $\mathrm{FC}$ \\
\hline Wong et al (2007) & Q: 84.1-04.2 & Hong Kong (I) & TA & Y RC SC D & $\begin{array}{l}\text { SARIMA ADLM } \\
\text { ECM VAR }\end{array}$ & FC CF \\
\hline
\end{tabular}


Table 2 Summary of Tourism Demand Modelling and Forecasting Studies on Greater China Published in Chinese Journals (1992-2007)

\begin{tabular}{|c|c|c|c|c|c|c|}
\hline Study & $\begin{array}{l}\text { Data Frequency } \\
\text { and Sample (1) }\end{array}$ & $\begin{array}{l}\text { Region Focused } \\
\text { (2) }\end{array}$ & $\begin{array}{l}\text { Dependent } \\
\text { Variable (3) }\end{array}$ & $\begin{array}{l}\text { Independent } \\
\text { Variable (4) }\end{array}$ & $\begin{array}{l}\text { Modelling and } \\
\text { Forecasting } \\
\text { Methods (5) }\end{array}$ & $\begin{array}{l}\text { Forecasting } \\
\text { exercise (6) }\end{array}$ \\
\hline Bai \& Wu (2003) & $\begin{array}{l}\text { A: } 84-99 \\
\text { CS: } 99\end{array}$ & Mainland China (I) & TA & Y/P P Dis DT & SR TEMs & Ex ante \\
\hline Bao (1992) & CS: 85.06 & Beijing (D) & TA & $\begin{array}{l}\text { Y/P Y/P/TS P } \\
\text { Dis TT }\end{array}$ & GraM & \\
\hline $\begin{array}{l}\text { Bian \& Song } \\
(2007)\end{array}$ & A: $98-05$ & Jingxia Province (I) & TA & & $\mathrm{MC}$ & \\
\hline Bu (2004) & A: $90-00$ & $\begin{array}{l}\text { Nanwan Scenic } \\
\text { Spot (D) }\end{array}$ & TA & DT & TEMs & $\begin{array}{l}\mathrm{FC} \\
\text { Ex ante }\end{array}$ \\
\hline Bu \& Zhao (2005) & A: $91-00$ & $\begin{array}{l}\text { Nanwan Scenic } \\
\text { Spot (D) }\end{array}$ & TE & DT & TEM & Ex ante \\
\hline Cai (2006) & A: $94-04$ & $\begin{array}{l}\text { Nanyue Scenic } \\
\text { Spot (D) }\end{array}$ & TA & DT & TEMs & $\begin{array}{l}\mathrm{FC} \\
\text { Ex ante }\end{array}$ \\
\hline $\begin{array}{l}\text { Cai \& Wang } \\
(2006)\end{array}$ & A: $94-04$ & $\begin{array}{l}\text { Nanyue Scenic } \\
\text { Spot }\end{array}$ & TA & DT & TEMs GM & $\begin{array}{l}\mathrm{FC} \\
\text { Ex ante }\end{array}$ \\
\hline $\begin{array}{l}\text { Cao \& Chang } \\
\text { (2006) }\end{array}$ & M: 00.01-04.03 & Shanghai (D+I) & TA & & ARIMA & Ex post \\
\hline $\begin{array}{l}\text { Cao \& Chen } \\
\text { (2005) }\end{array}$ & A: $93-04$ & $\begin{array}{l}\text { Fuzhou Forecast } \\
\text { Park (D) }\end{array}$ & TA & DT & TEMs & $\begin{array}{l}\mathrm{FC} \\
\text { Ex ante }\end{array}$ \\
\hline Che (2004) & CS: 01 & $\begin{array}{l}\text { Southeast Hubei } \\
\text { Province (D) }\end{array}$ & TA & P Dis OEIs & GraM & \\
\hline $\begin{array}{l}\text { Che \& Huang } \\
\text { (2003) }\end{array}$ & CS: 02 & $\begin{array}{l}\text { Southeast Hubei } \\
\text { Province (D) }\end{array}$ & TA & P Dis OEIs & GraM & \\
\hline Chen C (2007) & A: $98-05$ & $\begin{array}{l}\text { Taiwan to Fujian } \\
\text { Province }\end{array}$ & TA & DT & GM & Ex ante \\
\hline Chen (2002) & A: $87-01$ & $\begin{array}{l}\text { Lantsang-Mekong } \\
\text { Hypo-region (I) }\end{array}$ & TA & DT & TEM & Ex ante \\
\hline Chen (2006) & A: $00-05$ & Xi'an City (D+I) & TA & & GM & Ex ante \\
\hline Chen YY (2007) & A: $95-03$ & Henan Province (I) & TA TE/P & DT & TEM & Ex ante \\
\hline $\begin{array}{l}\text { Chen, Chen et al } \\
(2005)\end{array}$ & A: $79-04$ & $\begin{array}{l}\text { Yunnan Province } \\
\text { (I) }\end{array}$ & TA TE & & $\mathrm{NN}$ & Ex ante \\
\hline $\begin{array}{l}\text { Chen, Liu et al } \\
(2005)\end{array}$ & A: $80-03$ & $\begin{array}{l}\text { Mainland China } \\
(D+I)\end{array}$ & TA TE & & SA & Ex ante \\
\hline Chen et al (2007) & A: $00-04$ & $\begin{array}{l}\text { Tunxi District of } \\
\text { Huangshan City } \\
(D+I)\end{array}$ & TA & DT & TEM & Ex ante \\
\hline $\begin{array}{l}\text { Chen \& Zhang } \\
\text { (2007) }\end{array}$ & A: $97-06$ & Chongqing City (I) & TA TE & DT & TEMs & Ex ante \\
\hline Deng \& Lu (2006) & A: $90-05$ & Mainland China (I) & TA & & TEM ES AR NN & $\begin{array}{l}\mathrm{FC} \\
\text { Ex ante }\end{array}$ \\
\hline $\begin{array}{l}\text { Dong \& Fang } \\
\text { (2006) }\end{array}$ & A: $83-04$ & $\begin{array}{l}\text { Mount Wuyi } \\
\text { Scenic Spot (D) }\end{array}$ & TA & DT & TEM & Ex ante \\
\hline Fan (2004) & Q: 97.1-03.1 & Beijing (I) & TA & DT & TEM & Ex post \\
\hline Feng (2004) & CS: 99 & $\begin{array}{l}\text { Yangtzi River } \\
\text { Delta (D) to } \\
\text { Shanghai Expo }\end{array}$ & TA & Y P TA/P C $\mathrm{C}_{\mathrm{d}} \mathrm{TS}$ & GraM & Ex ante \\
\hline Gao (2002) & A: $95-00$ & Xi'an City (I) & TA & & GM & Ex ante \\
\hline Ge \& Hua (2006) & $\begin{array}{l}\text { D: } 2003 / 2005- \\
\text { Godden weeks }\end{array}$ & $\begin{array}{l}\text { Yunnan Province } \\
\text { (D) }\end{array}$ & TA & DT & GM & Ex post \\
\hline Gou \& Sun (2000) & A: $78-97$ & Shanghai $(\mathrm{D}+\mathrm{I})$ & TA TE & DT & TEM & Ex ante \\
\hline
\end{tabular}




\begin{tabular}{|c|c|c|c|c|c|c|}
\hline Guan (1999) & A: $90-95$ & $\begin{array}{l}\text { Mount Wuyi } \\
\text { Scenic Spot (D) }\end{array}$ & TA & DT & TEM Naïve 2 & Ex ante \\
\hline Guan et al (1998) & A: $91-96$ & Lijiang Region (D) & TA & DT & TEM & Ex ante \\
\hline Guo (2007) & A: $85-06$ & Mainland China(D) & TA & & ARIMA & $\begin{array}{l}\text { Ex post } \\
\text { Ex ante }\end{array}$ \\
\hline Guo \& Ou (2007) & M: 05.01-06.02 & Guilin City (D+I) & TA & DT & TEM & $\begin{array}{l}\text { Ex post } \\
\text { Ex ante }\end{array}$ \\
\hline $\begin{array}{l}\text { Han \& Zhou } \\
(2002)\end{array}$ & A: $78-00$ & $\begin{array}{l}\text { Mainland China } \\
(D+I)\end{array}$ & TA TE & $\begin{array}{l}\text { Y Y/P DT TA/P } \\
\text { P D OEI }\end{array}$ & SR ES & Ex ante \\
\hline He \& Deng (2007) & M: 99.01-06.10 & Guilin City (D) & TA & & SARIMA & Ex post \\
\hline He \& Ye (2006) & A: $85-04$ & Mainland China(D) & $\mathrm{TE}$ & $\mathrm{Y}$ & VAR & \\
\hline Huang (2005) & A: $93-05$ & Mainland China (I) & TA TE & DT & TEM & Ex ante \\
\hline Jia \& Yu (2004) & A: $93-02$ & Dalian City (I) & $\mathrm{TE}$ & DT & TEMs & Ex ante \\
\hline Jiang et al (2007) & A: $93-03$ & $\begin{array}{l}\text { Yunnan Province, } \\
\text { Lantsang-Mekong } \\
\text { Hypo-region (I) }\end{array}$ & TA & & MA & Ex ante \\
\hline Kang et al (2006) & A: $01-04$ & $\begin{array}{l}\text { Mainland China } \\
\text { (D) }\end{array}$ & $\begin{array}{l}\text { TE- } \\
\text { e-tourism }\end{array}$ & DT & TEM GM & $\begin{array}{l}\mathrm{FC} \\
\text { Ex ante }\end{array}$ \\
\hline Lei \& Chen (2007) & A: $80-04$ & Mainland China (I) & $\mathrm{TA}$ & & $\begin{array}{l}\text { ARIMA NN } \\
\text { ARIMA+NN }\end{array}$ & $\begin{array}{l}\mathrm{FC} \\
\text { Ex ante }\end{array}$ \\
\hline $\operatorname{Li}(2001)$ & A: $78-98$ & Mainland China (I) & TA & DT & TEMs & $\begin{array}{l}\mathrm{FC} \text { ex ante } \\
\mathrm{CF}\end{array}$ \\
\hline Li (2003) & A: $78-00$ & Mainland China (I) & TE & DT & TEM & Ex ante \\
\hline $\operatorname{Li}(2005)$ & A: $95-04$ & Mainland China(D) & $\mathrm{TE}$ & $\mathrm{Y} / \mathrm{P} \mathrm{C}_{\mathrm{d}}$ & ARDL & \\
\hline Li et al (2007) & A: $94-05$ & $\begin{array}{l}\text { Xinjiang Province } \\
\text { (I) }\end{array}$ & TA & DT & TEM & \\
\hline Li \& Su (2006) & A: $95-04$ & $\begin{array}{l}\text { Guilin City (I) from } \\
\text { US }\end{array}$ & TA & TS OEIs & GraM & \\
\hline Li \& Sun (1998) & A: $78-95$ & Xi'an City (I) & $\mathrm{TA}$ & DT & TEM & Ex ante \\
\hline Li \& Xie (1993) & A: $79-90$ & $\begin{array}{l}\text { Huangshan Scenic } \\
\text { Spot (D) }\end{array}$ & TA-by air & $\mathrm{Y} / \mathrm{P}$ & SR & Ex ante \\
\hline Liu (2003) & A: 95-01 & Shanghai (I) & $\mathrm{TA}$ & DT & GM & Ex ante \\
\hline Liu \& Cui (2004) & A: $94-02$ & $\begin{array}{l}\text { Inner-Mongolia } \\
\text { Province (D) }\end{array}$ & TE-on road & DT P Y & TEM SR GM & $\begin{array}{l}\mathrm{FC} \\
\text { Ex ante }\end{array}$ \\
\hline Liu et al (2006) & A: $79-04$ & Jiangxi Province (I) & TA & DT & TEM & Ex ante \\
\hline Liu et al (2007) & A: $00-02$ & $\begin{array}{l}\text { Mianyang Scenic } \\
\text { Spot (D) }\end{array}$ & TA & DT & TEM & Ex ante \\
\hline $\mathrm{Lu}(2005)$ & A: $90-04$ & Mainland China (I) & TA TE & DT & TEMs & $\begin{array}{l}\mathrm{FC} \\
\text { Ex ante }\end{array}$ \\
\hline $\mathrm{Lu}(2007 \mathrm{a})$ & A: $93-03$ & Mainland China(D) & TA TE & $\mathrm{C}_{\mathrm{d}}$ OEIs & $\mathrm{NN}$ & Ex post \\
\hline $\mathrm{Lu}(2007 b)$ & A: $95-05$ & $\begin{array}{l}\text { Mainland China } \\
\text { (D) }\end{array}$ & TA TE & OEIs & SR & Ex post \\
\hline Lu et al (2002) & A: $94-00$ & $\begin{array}{l}\text { Shahu Scenic Sport } \\
\text { (D) }\end{array}$ & $\mathrm{TE}$ & & GM & $\begin{array}{l}\text { Ex post } \\
\text { Ex ante }\end{array}$ \\
\hline Luo \& Hou (2000) & A: $85-99$ & Hunan Province (I) & $\mathrm{TE}$ & DT & TEMs & Ex ante \\
\hline $\begin{array}{l}\text { Luo \& Zhang } \\
(2005)\end{array}$ & A: $95-03$ & $\begin{array}{l}\text { Jiangsu Province } \\
\text { (D) }\end{array}$ & TA TE & & GM & Ex ante \\
\hline Ma (2007) & A: $00-06$ & Mainland China(D) & TA & DT & TEM & Ex ante \\
\hline Mao (2000) & A: $85-94$ & $\begin{array}{l}\text { Simian Mountain } \\
\text { Scenic Spot (D) }\end{array}$ & TA & DT & TEM MA ES & $\mathrm{FC}$ \\
\hline Mei et al (2007) & A: $00-05$ & Mainland China(D) & TA-by air & DT & TEMs & Ex ante \\
\hline Nie (2001) & A: $80-98$ & Mainland China (I) & TA TE & DT & TEMs & Ex ante \\
\hline $\begin{array}{l}\text { Ou \& Zhang } \\
(2005)\end{array}$ & A: $97-02$ & Hebei Province (D) & TA & DT & GM & $\begin{array}{l}\text { Ex post } \\
\text { Ex ante }\end{array}$ \\
\hline
\end{tabular}




\begin{tabular}{|c|c|c|c|c|c|c|}
\hline Peng \& Qu (2003) & A: $96-01$ & $\begin{array}{l}\text { Yunyang Forest } \\
\text { Park (D) }\end{array}$ & $\mathrm{TA}$ & & GM & Ex ante \\
\hline Qin (2000) & A: 73-99 & Guilin City (I) & TA & DT & MA+TEM & Ex ante \\
\hline Qin (2005) & A: $80-02$ & Guilin City (D) & TA & $\mathrm{Y} / \mathrm{P}$ & MA SR & Ex ante \\
\hline Qin et al (2006) & M: 89.01-02.12 & Guilin City (D+I) & TA-by air & & ES SARIMA NN & $\mathrm{FC}$ \\
\hline Ren \& Liu (2006a) & M: 89.01-04.12 & Mainland China (I) & TA & & ES ARMA & $\mathrm{FC}$ \\
\hline $\begin{array}{l}\text { Shang \& Qin } \\
(2007)\end{array}$ & M: 01.01-05.03 & Mainland China (I) & $\mathrm{TE}$ & & ARIMA GARCH & $\mathrm{FC}$ \\
\hline Shen (1999) & A: $90-96$ & Henan Province (I) & TA & DT & TEM & Ex ante \\
\hline Shen (2005) & A: $95-04$ & Henan Province (I) & TA & DT & TEM & Ex ante \\
\hline Shi (2005) & A: $97-02$ & Mainland China (I) & TA & DT & GM & Ex ante \\
\hline Shi et al (2007) & A: $96-04$ & $\begin{array}{l}\text { Xinjiang Province } \\
\text { (I) }\end{array}$ & TA TE & & TEM & Ex ante \\
\hline $\begin{array}{l}\text { Shui \& Teng } \\
\text { (2006) }\end{array}$ & A: $97-02$ & $\begin{array}{l}\text { Leshan Scenic Spot } \\
\text { (D) }\end{array}$ & TA & $\mathrm{Y} / \mathrm{P} \mathrm{C}_{\mathrm{d}} \mathrm{OEI}$ & SR & Ex post \\
\hline $\mathrm{Su}(2006)$ & A: $98-04$ & Qinghai Province(I) & TA & DT & GM & Ex ante \\
\hline Sun (1998) & A: $84-96$ & Mainland China (I) & TA & DT & TEMs & Ex ante \\
\hline Sun (2000) & A: $84-96$ & Mainland China (I) & TA & DT & TEMs & Ex ante \\
\hline Sun (2001) & A: $78-99$ & Xi'an City (I) & TA TE & DT & TEM & \\
\hline Sun \& Hou (2004) & A: $78-04$ & $\begin{array}{l}\text { Mainland China } \\
(\mathrm{D}+\mathrm{I})\end{array}$ & TA TE & $\begin{array}{l}\text { Y Y/P DT TA/P } \\
\text { P D OEI }\end{array}$ & SR ES & Ex ante \\
\hline Sun \& Ma (2007) & M: 00.01-02.12 & Xi'an City (D+I) & TA & OEI D & SR & \\
\hline Sun et al (1998) & A: $89-95$ & Kunming City (I) & TA & DT & TEM GM & Ex ante \\
\hline Sun et al (2002) & A: $80-99$ & Mainland China (I) & TA & DT & TEM NN & $\begin{array}{l}\mathrm{FC} \\
\text { Ex ante }\end{array}$ \\
\hline $\begin{array}{l}\text { Tang, Zhao \& Qin } \\
\text { (2007) }\end{array}$ & A: $97-04$ & Guilin city $(D+I)$ & TA & DT & GM & Ex ante \\
\hline $\begin{array}{l}\text { Tang, Zhou \& } \\
\text { Zhang (2007) }\end{array}$ & Q: 94.1-05.4 & $\begin{array}{l}\text { Mainland China } \\
\text { (D) }\end{array}$ & TA & & ES & \\
\hline $\begin{array}{l}\text { Tang, Zhou, } \\
\text { Zhang \& Zhang } \\
\text { (2007) }\end{array}$ & Q: 94.1-05.4 & Mainland China(D) & TA & & ES & Ex ante \\
\hline Teng \& Li (2006) & A: $78-05$ & Xi'an City (I) & TA & & NNs & $\begin{array}{l}\mathrm{FC} \\
\text { Ex ante }\end{array}$ \\
\hline Tian (2001) & A: $91-00$ & $\begin{array}{l}\text { Chongqing City (I) } \\
\text { from US }\end{array}$ & TA & DT & TEM & Ex ante \\
\hline Wang (2000) & A: $94-04$ & Zibo City (I) & TA & DT & TEM & Ex ante \\
\hline Wang (2001) & A: $78-00$ & Mainland China (I) & TA TE & DT & GM & Ex ante \\
\hline Wang (2002) & A: $97-00$ & $\begin{array}{l}\text { Fuling District of } \\
\text { Chongqing City(D) }\end{array}$ & TA TA/P & Y/P P OEIs & SR & Ex ante \\
\hline Wang (2003) & A: $93-00$ & Mainland China (I) & TA & DT & TEMs & Ex ante \\
\hline Wang (2004) & $\mathrm{W}: 00.3^{\mathrm{rd}}-04.3^{\mathrm{rd}}$ & Mainland China(D) & TA & DT & GM & Ex ante \\
\hline Wang (2006) & A: $96-03$ & $\begin{array}{l}\text { Shennongiia } \\
\text { District (D) }\end{array}$ & $\mathrm{TE}$ & DT & TEM & Ex ante \\
\hline $\begin{array}{l}\text { Wang \& Hua } \\
(2006)\end{array}$ & D: 05 & $\begin{array}{l}\text { Yunnan Province } \\
\text { (D) }\end{array}$ & $\mathrm{TA}$ & DT & TEM & Ex ante \\
\hline Wang et al (2004) & A: $79-02$ & Mainland China (I) & $\mathrm{TE}$ & $\mathrm{Y} \mathrm{Y}_{\mathrm{d}}$ OEIs & SR & \\
\hline Wang et al (1997) & A: $83-94$ & Beijing (I) & TA & & TEMs & \\
\hline Wei (1999) & A: $88-95$ & Shenzhen City (I) & TA & DT & GM & Ex ante \\
\hline Wei (2000) & A: $91-96$ & Shanghai (I) & TA & & GM & Ex ante \\
\hline Wei \& Liu (1997) & A: $79-95$ & Xi'an City (I) & TA & & ARIMA & $\begin{array}{l}\text { Ex post } \\
\text { Ex ante }\end{array}$ \\
\hline Wei \& Yu (2005) & M: 01.01-02.08 & Beijing (I) & TA & DT & TEM & Ex ante \\
\hline
\end{tabular}




\begin{tabular}{|c|c|c|c|c|c|c|}
\hline Wei et al (2005) & A: $78-02$ & $\begin{array}{l}\text { Shandong Province } \\
\text { (I) }\end{array}$ & TA & DT & TEM & \\
\hline Wu et al (2002) & A: $67-97$ & $\begin{array}{l}\text { Hong Kong from } \\
\text { Japan }\end{array}$ & TA & $\begin{array}{l}\text { C HR EX P ME } \\
\text { Y/P }\end{array}$ & ES MA AR NN & $\mathrm{FC}$ \\
\hline Wu \& Liu (2001) & A: $78-98$ & Mainland China (I) & $\mathrm{TE}$ & & AR MA ARMA & Ex ante \\
\hline Xie (2007) & M: 97.01-03.08 & Beijing (I) & $\mathrm{TA}$ & & TEM & \\
\hline Xie \& Wu (1998) & M: 93.01-96.12 & An unnamed hotel & TA-hotels & DT & TEM & Ex ante \\
\hline $\mathrm{Xu}(2000)$ & A: $83-99$ & $\begin{array}{l}\text { Sichuan Province } \\
\text { (D) }\end{array}$ & $\mathrm{TA}$ & $\mathrm{Y} / \mathrm{P}$ & SR & Ex ante \\
\hline Xu (2003) & A: $90-01$ & $\begin{array}{l}\text { Mainland China } \\
\text { (D) }\end{array}$ & TA TE & Y/P TA/P OEIs & GM & Ex ante \\
\hline $\begin{array}{l}\text { Xu \& Huang } \\
(2005)\end{array}$ & A: $97-03$ & Feshan City (D+I) & $\mathrm{TE}$ & $\begin{array}{l}\text { Y Y/P TA NAC } \\
\text { OEIs }\end{array}$ & GM & Ex ante \\
\hline Xu \& Yu (1997) & A: $82-91$ & $\begin{array}{l}\text { Jilin Province } \\
(\mathrm{D}+\mathrm{I})\end{array}$ & $\mathrm{TE}$ & OEIs & SR & \\
\hline $\begin{array}{l}\text { Yan \& Meng } \\
(2005)\end{array}$ & A: $84-02$ & $\begin{array}{l}\text { Suiyang County, } \\
\text { Guizhou (D) }\end{array}$ & TA & & TEM & Ex ante \\
\hline Yang (2001) & A: $84-95$ & Mainland China (I) & TA & DT & GM & Ex post \\
\hline Yang et al (2003) & M: 99.01-02.12 & $\begin{array}{l}\text { North Spa Scenic } \\
\text { Spot (D) }\end{array}$ & TA & DT & TEM & Ex ante \\
\hline Ye (2003) & A: $80-01$ & Mainland China (I) & TA & & TEM & Ex ante \\
\hline Yin et al (2004) & A: $83 / 94-02$ & $\begin{array}{l}\text { Yunnan Province } \\
(\mathrm{D}+\mathrm{I})\end{array}$ & TA & & SVMs & $\mathrm{FC}$ \\
\hline Yu (2006) & A: $95-05$ & Jilin Province (I) & $\mathrm{TE} / \mathrm{P}$ & OEIs & $\mathrm{SR}$ & \\
\hline $\begin{array}{l}\text { Yu \& Wang } \\
(2005)\end{array}$ & M: 93.01-04.07 & Mainland China (I) & $\mathrm{TA}$ & & ARIMA & Ex post \\
\hline Zhang EX(2000) & A: $83-97$ & Mainland China (I) & TA & DT & MC TEM & Ex ante \\
\hline Zhang (1995) & A: $84-92$ & $\begin{array}{l}\text { Unnamed forecast } \\
\text { Park (D) }\end{array}$ & TA & & GM & Ex ante \\
\hline Zhang (2003) & A: $93-02$ & $\begin{array}{l}\text { Mainland China } \\
(\mathrm{D}+\mathrm{I})\end{array}$ & $\mathrm{TE}$ & Y OEIs & SR & \\
\hline Zhang (2004) & A: 93-01 & Mainland China(D) & TA TE TE/P & Y Y/P P Dis DT & SRs TEMs & Ex ante \\
\hline Zhang (2007) & M: 94.01-05.12 & Mainland China (I) & $\mathrm{TE}$ & DT D & $\begin{array}{l}\text { TEM ARIMA } \\
\text { AR }\end{array}$ & $\begin{array}{l}\mathrm{FC} \\
\text { Ex ante }\end{array}$ \\
\hline $\begin{array}{l}\text { Zhang \& Chen } \\
\text { (2007) }\end{array}$ & SA: $57-06$ & $\begin{array}{l}\text { Canton Trade Fair } \\
\text { (D) }\end{array}$ & TA & & ARIMA & Ex ante \\
\hline Zhang et al (2000) & A: $90-97$ & $\begin{array}{l}\text { Hebei Province (I) } \\
\text { Aggregate and US }\end{array}$ & TA & $\mathrm{P}$ Dis OEIs & GraM & Ex ante \\
\hline Zhang et al (2007) & A: $95-05$ & $\begin{array}{l}\text { Mainland China (D, } \\
\text { I) }\end{array}$ & TA TE & $\mathrm{Y} / \mathrm{P}$ & SR & Ex ante \\
\hline Zhang \& Li (2007) & A; $00-05$ & Hebei Province (I) & TA & & GM & Ex ante \\
\hline $\begin{array}{l}\text { Zhang \& Lu } \\
(2004)\end{array}$ & A/M: 78.01-02.12 & Mainland China (I) & TA & & MA & \\
\hline $\begin{array}{l}\text { Zhang \& Ma } \\
(2005)\end{array}$ & A: $78-03$ & Mainland China (I) & TA & DT & AR GM & $\begin{array}{l}\mathrm{FC} \\
\text { Ex ante }\end{array}$ \\
\hline $\begin{array}{l}\text { Zhang \& Wang } \\
\text { (2002) }\end{array}$ & A: $92-00$ & $\begin{array}{l}\text { Ningxia Province } \\
\text { (D) }\end{array}$ & TA & $\mathrm{Y}_{\mathrm{d}}$ & $\mathrm{HM}$ & Ex ante \\
\hline $\begin{array}{l}\text { Zhang \& Wang } \\
\text { (2005) }\end{array}$ & A: $98-02$ & $\begin{array}{l}\text { Shaanxi Province } \\
\text { (I) }\end{array}$ & TA TE & DT & TEM & Ex ante \\
\hline Zhao (2004) & A: $98-02$ & $\begin{array}{l}\text { An unnamed scenic } \\
\text { Spot (D) }\end{array}$ & TA & DT & TEM & Ex ante \\
\hline Zhao \& Jia (2005) & A: $98-02$ & $\begin{array}{l}\text { Anhui Province } \\
(\mathrm{D}+\mathrm{I})\end{array}$ & $\mathrm{TE}$ & & GM & Ex ante \\
\hline Zhao et al (2006) & $\begin{array}{l}\text { D: 00.01.01- } \\
02.11 .30\end{array}$ & $\begin{array}{l}\text { Tianyahaijiao } \\
\text { Scenic Spot (D) }\end{array}$ & TA & & $\mathrm{NN}$ & Ex post \\
\hline
\end{tabular}




\begin{tabular}{|c|c|c|c|c|c|c|}
\hline $\begin{array}{l}\text { Zhao \& Yin } \\
\text { (2004) }\end{array}$ & CS: 02 & $\begin{array}{l}\text { Shenmu County } \\
\text { (D) }\end{array}$ & TA & $\begin{array}{l}\text { Y/P Dis TT } \\
\text { OEIs }\end{array}$ & GraM & Ex ante \\
\hline $\begin{array}{l}\text { Zheng \& Liu } \\
\text { (2001) }\end{array}$ & A: $90-99$ & $\begin{array}{l}\text { Xinjiang Province } \\
\text { (I) }\end{array}$ & TA & DT & TEMs & $\begin{array}{l}\text { Ex post } \\
\text { Ex ante } \\
\text { CF }\end{array}$ \\
\hline $\begin{array}{l}\text { Zheng \& Zhu } \\
\text { (2006) }\end{array}$ & A: $97-04$ & Dazhou City (D) & TA & DT & TEMs & Ex ante \\
\hline $\begin{array}{l}\text { Zhou \& Liu } \\
\text { (1996) }\end{array}$ & A: $78-94$ & Kunming City (I) & TA & DT & TEMs & $\begin{array}{l}\text { FC } \\
\text { Ex ante } \\
\text { CF }\end{array}$ \\
\hline $\begin{array}{l}\text { Zhou \& Ren } \\
\text { (2004) }\end{array}$ & A: $97-02$ & Mainland China (I) & TA & DT & GM & Ex ante \\
\hline Zhu et al (2005) & A: $78-98$ & Mainland China (I) & TA & DT & GMs & FC \\
\hline Zhu et al (2006) & A: $00-04$ & $\begin{array}{l}\text { Zaozhuang City } \\
\text { (D) }\end{array}$ & TA & DT & $\mathrm{GM}+\mathrm{NN}$ & Ex ante \\
\hline Zhu \& Pan (2005) & A: $92-03$ & $\begin{array}{l}\text { Nanwan Scenic } \\
\text { Spot (D) }\end{array}$ & TA & & GM & Ex ante \\
\hline
\end{tabular}


Table 3 Summary of Geographic Focuses of the Surveyed Studies

\begin{tabular}{lc|lcc}
\hline \multicolumn{2}{c|}{ International Studies } & \multicolumn{3}{c}{ Chinese Studies } \\
$\begin{array}{l}\text { Geographic } \\
\text { focus }\end{array}$ & $\begin{array}{c}\text { No. of } \\
\text { studies }\end{array}$ & Geographic & $\begin{array}{c}\text { Total no. } \\
\text { of studies }\end{array}$ & $\begin{array}{c}\text { No. of studies on } \\
\text { international demand }\end{array}$ \\
\hline Mainland China & 11 & National aggregate & 45 & 28 \\
Hong Kong & 26 & Provinces & 42 & 25 \\
Macau & 1 & Cities/towns & 27 & 14 \\
Taiwan & 9 & Scenic Sports & 17 & -- \\
& & Others & 6 & -- \\
\hline
\end{tabular}


Table 4 Summary of the Calculated Tourism Demand Elasticities

\begin{tabular}{|c|c|c|c|}
\hline Region under study & Income elasticity & Price elasticity & Source \\
\hline Hong Kong (I)* & 1.948 & -1.025 & Song et al (2003) \\
\hline & $(0.944 \sim 3.620)$ & $(-2.885 \sim-0.206)$ & \\
\hline Hong Kong (I)* & $\begin{array}{c}1.922 \\
(0.233 \sim 2.907)\end{array}$ & $\begin{array}{c}-0.561 \\
(-1.013 \sim-0.175)\end{array}$ & Song \& Wong (2003) \\
\hline Mainland China (I)* & $\begin{array}{c}3.387 \\
(1.916 \sim 4.841)\end{array}$ & $\begin{array}{c}-4.132 \\
(-11.751 \sim-0.930)\end{array}$ & Song \& Fei (2007) \\
\hline Mainland China (D) & 0.733 & -- & Cai \& Knutson (1998) \\
\hline Mainland China to Hong Kong & 1.521 & -0.402 & Song et al (2003) \\
\hline Taiwan to Mainland China & 1.916 & -- & Song \& Fei (2007) \\
\hline Taiwan to Hong Kong & 2.140 & -1.729 & Song et al (2003) \\
\hline
\end{tabular}


Table 5 Summary of Forecasting Exercises in the Surveyed Literature Forecasting Expost Exante Forecast No competition forecasting forecasting combination forecasting

$\begin{array}{llllll}\text { International studies } & 17 & 8 & 6 & 1 & 12\end{array}$

Chinese studies

21

16

101

3

19 


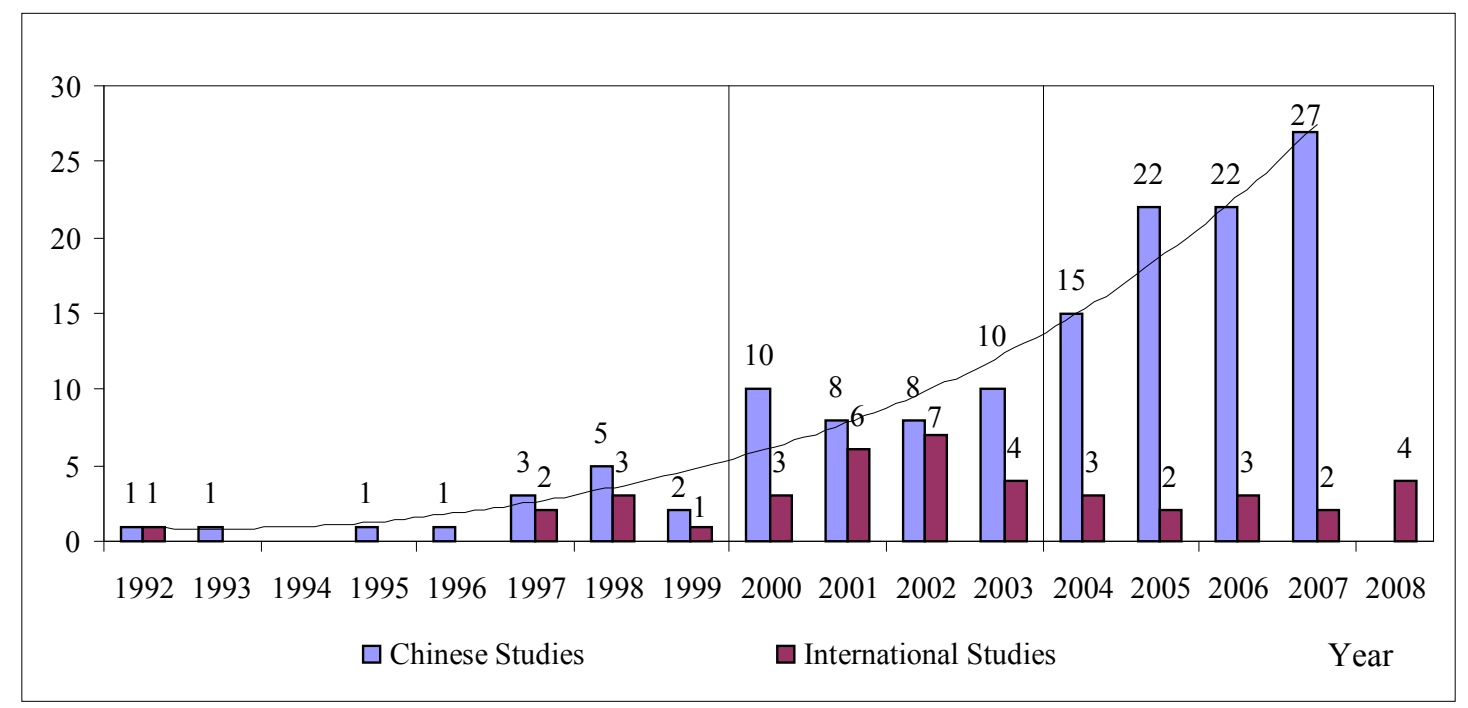

Figure 1. Publications of Tourism Demand Studies on Grater China (1992-2008) 